\title{
Coordinate Transcriptomic and Metabolomic Effects of the Insulin Sensitizer Rosiglitazone on Fundamental Metabolic Pathways in Liver, Soleus Muscle, and Adipose Tissue in Diabetic db/db Mice
}

\author{
Sabrina Le Bouter, ${ }^{1}$ Marianne Rodriguez, ${ }^{1}$ Nolwen Guigal-Stephan, ${ }^{1}$ \\ Sophie Courtade-Gaiani, ${ }^{1}$ Laura Xuereb, ${ }^{2}$ Catherine de Montrion, ${ }^{1}$ Vincent Croixmarie, ${ }^{3}$ \\ Thierry Umbdenstock, ${ }^{3}$ Claire Boursier-Neyret, ${ }^{3}$ Michel Lonchampt, ${ }^{4}$ Manuel Brun, ${ }^{4}$ \\ Catherine Dacquet, ${ }^{4}$ Alain Ktorza, ${ }^{4}$ Brian-Paul Lockhart, ${ }^{1}$ and Jean-Pierre Galizzi ${ }^{1}$ \\ ${ }^{1}$ Division of Molecular Pharmacology and Pathophysiology, Institut de Recherches Servier, 125 Chemin de Ronde, \\ 78290 Croissy-sur-Seine, France \\ ${ }^{2}$ Department of Biostatistics, Institut de Recherches Servier, 11 rue des Moulineaux, 92150 Suresnes, France \\ ${ }^{3}$ Metabolisme BA, Technologie Servier, 5 rue Bel Air, 45000 Orleans, France \\ ${ }^{4}$ Division of Diabetes Metabolic Diseases Research, Institut de Recherches Servier, 11 rue des Moulineaux, 92150 Suresnes, France
}

Correspondence should be addressed to Jean-Pierre Galizzi, jean-pierre.galizzi@fr.netgrs.com

Received 29 April 2010; Revised 16 July 2010; Accepted 11 August 2010

Academic Editor: Chih-Hao Lee

Copyright (C) 2010 Sabrina Le Bouter et al. This is an open access article distributed under the Creative Commons Attribution License, which permits unrestricted use, distribution, and reproduction in any medium, provided the original work is properly cited.

Rosiglitazone (RSG), developed for the treatment of type 2 diabetes mellitus, is known to have potent effects on carbohydrate and lipid metabolism leading to the improvement of insulin sensitivity in target tissues. To further assess the capacity of RSG to normalize gene expression in insulin-sensitive tissues, we compared groups of 18 -day-treated $\mathrm{db} / \mathrm{db}$ mice with increasing oral doses of RSG $(10,30$, and $100 \mathrm{mg} / \mathrm{kg} / \mathrm{d})$ with untreated non-diabetic littermates $(\mathrm{db} /+)$. For this aim, transcriptional changes were measured in liver, inguinal adipose tissue (IAT) and soleus muscle using microarrays and real-time PCR. In parallel, targeted metabolomic assessment of lipids (triglycerides (TGs) and free fatty acids (FFAs)) in plasma and tissues was performed by UPLCMS methods. Multivariate analyses revealed a relationship between the differential gene expressions in liver and liver trioleate content and between blood glucose levels and a combination of differentially expressed genes measured in liver, IAT, and muscle. In summary, we have integrated gene expression and targeted metabolomic data to present a comprehensive overview of RSGinduced changes in a diabetes mouse model and improved the molecular understanding of how RSG ameliorates diabetes through its effect on the major insulin-sensitive tissues.

\section{Introduction}

Type 2 diabetes, also known as non-insulin-dependent diabetes mellitus, is a chronic disease that affects more than 100 million people worldwide, and its prevalence is soaring in western countries driven by high-fat diets and sedentary lifestyles. This pathology is characterized by resistance to the effects of insulin in peripheral tissues, which is manifested as reduced insulin-stimulated glucose uptake into skeletal muscle and adipose tissue, defective insulin-dependent suppression of hepatic glucose output, and reduced insulin secretion from pancreatic $\beta$-cells. Insulin-sensitising drugs, such as RSG, are widely used in clinical practice to improve diabetes alteration in glucose metabolism. Thiazolidinediones (TZDs) are already known to decrease blood glucose concentration, to improve liver and muscle insulin sensitivity $[1,2]$, and to have significant impact on adipose tissue by inducing adipose differentiation, lipogenesis, and TG 
storage [3-6]. The mechanisms of action of TZDs are mediated through binding and activation of the peroxisome proliferator-activated receptor $\gamma(\operatorname{PPAR} \gamma)$, a nuclear receptor that has a regulatory role in lipid metabolism and in cell differentiation, particularly in adipocytes $[7,8]$. PPAR $\gamma$ is also expressed in several other tissues, including muscle, liver, pancreas, heart, and spleen [9]. Among the multiple actions of TZDs is the normalisation of blood glucose level, by increasing glucose uptake and decreasing hepatic glucose production [10]. Moreover, TZDs induce shifts in systemic lipid profiles, with a decrease in FFAs and TGs levels in the circulation, partly by improving adipocyte function [11]. Taken together, these effects on carbohydrate and lipid metabolism are associated with the improvement of insulin sensitivity of peripheral tissues. However, TZDs actions are also accompanied by increased adipogenesis and lipid accumulation in tissues [12,13]. RSG is a prototype of the TZD chemical class developed for the treatment of type 2 diabetes mellitus, and some of these effects are known to be mediated via gene transcriptional regulation [14-17]; however, the relationship between the RSG-mediated gene expression regulation in insulin-dependent tissues and the subsequent physiological changes remains unclear.

Diabetic $\mathrm{db} / \mathrm{db}$ mice, which have a defect in the leptin receptor, reproduce many of the metabolic disturbances present in patients with type II diabetes mellitus, including hyperglycaemia, hyperinsulinemia, hyperlipidemia, and insulin resistance [18]. To address the question of whether RSG-mediated normalisation of blood and tissue biological characteristics in treated $\mathrm{db} / \mathrm{db}$ is accompanied by normalized gene expression in three major insulin-dependent tissues, liver, IAT (inguinal adipose tissue), and skeletal muscle, we analysed transcriptomic profiles of RSG-treated diabetic mice $\mathrm{db} / \mathrm{db}$ and compared them with those of untreated non diabetic littermates $\mathrm{db} /+$. Multivariate analysis was then used to establish relationships between the RSG-regulated gene expression profiles and metabolomic data obtained from the insulin-sensitive tissues or blood samples.

This study provides a comprehensive evaluation of RSG-induced changes in genome-wide expression and its relationships with RSG-mediated physiological changes in three main insulin-sensitive tissues known to be involved in lipid and glucose homeostasis.

\section{Materials and Methods}

2.1. Animals and Treatment. An eight-week old male BKSCg-m+/+ Leprdb/J diabetic (db/db) mice and their nondiabetic strain $(\mathrm{db} /+)$ were obtained from Charles River Laboratories (L'Arbresle, France). Three animals were housed per cage and acclimatised for 1 week under standard light ( $12 \mathrm{~h}$ light/dark), feeding (db/+: standard laboratory chow (A03, Safe, France); db/db: 5K52, Safe, France). Mice were randomly divided into 5 different groups $(n=$ 6/group) as follows: vehicle- (1\% HEC-) treated nondiabetic $\mathrm{db} /+$ and diabetic $\mathrm{db} / \mathrm{db}$ mice (control $\mathrm{db} / \mathrm{db}$ mice), and diabetic $\mathrm{db} / \mathrm{db}$ mice treated orally with the PPAR $\gamma$ agonist RSG (Syntheval, Caen, France) at 3 separate doses
$(10,30,100 \mathrm{mg} / \mathrm{kg} /$ day $)$ for 18 days. Body weight was measured daily, and blood was collected by orbital sinus puncture before and after treatment (18h after the last treatment) to assess glucose levels. All experimental procedures were in accordance with the International European Ethical Standards (86/609-EEC) and the French National Committee (decree 87/848) for the care and use of laboratory animals.

2.2. Tissue and Blood Analyses. At the end of treatment, mice were euthanized by cervical dislocation. Liver, IAT, and soleus muscle were immediately taken, weighed, flash frozen in liquid nitrogen, and kept at $-80^{\circ} \mathrm{C}$. Blood samples were drawn into heparin-containing tubes (1.5 I.U. heparin for $100 \mu \mathrm{L}$ of blood), and plasma was aliquoted and stored at $4^{\circ} \mathrm{C}$. Blood glucose, $\mathrm{Hb}$, and $\mathrm{HbAlc}$ levels were determined using the automatic analyser COBAS system (Roche, Basel, Switzerland). FFA and TG Liver and adipose tissues (50 mg aliquots) were extracted with $\mathrm{CHCl}_{3}$. After evaporation, the organic dry extract was reconstituted in $\mathrm{CH}_{3} \mathrm{CN} / \mathrm{iPrOH}$ (1/1). Plasma $(50 \boldsymbol{\mu} \mathrm{L})$ was extracted with a mixture of $\mathrm{CHCl}_{3} / \mathrm{MeOH}(2 / 1)$. FFA and TG analyses were performed by UPLC-MS using a C18 BEH Acquity analytical column, a gradient of $\mathrm{CH}_{3} \mathrm{CN}, \mathrm{iPrOH}$, and formic acid $(0.1 \%)$ $\left(0.5 \mathrm{~mL} / \mathrm{min}, 50^{\circ} \mathrm{C}\right)$, and a 4000 QTRAP (Applied Biosystems, Foster City, CA, USA) and LCT premier (Waters).

2.3. RNA Preparation. Total RNA was prepared from frozen liver, soleus, and IAT, using Trizol reagent (Invitrogen, France) and was further purified by ammonium acetate precipitation according to standard protocols. Purified total RNA concentration and $260 / 280 \mathrm{~nm}$ or $260 / 230 \mathrm{~nm}$ ratios were determined using a Nanodrop ND-1000 spectrophotometer (Nyxor Biotech, France). Then, total RNA integrity was checked by microelectrophoresis on acrylamide gel (Agilent 2100 Bioanalyzer, Agilent, Santa Clara, CA, USA).

2.4. Microarray Hybridization and Data Analysis. Total RNA (500 ng) samples were labelled with cyanine Cy5- or Cy3CTP dyes using Agilent Low RNA Input Linear Amplification Kit (Agilent Technology, PN 5184-3523), according to the manufacturer's protocols. Following in vitro transcription, $825 \mathrm{ng}$ of test sample (individual $\mathrm{db} /+: n=6$ ) or RSGtreated $\mathrm{db} / \mathrm{db}$ cRNA were mixed with $825 \mathrm{ng}$ of reference sample (pooled: $n=6 \mathrm{db} / \mathrm{db}$ cRNA). The samples were hybridized (dye-swap replicates) on $4 \times 44 \mathrm{k}$ wholeGenome 60-mer oligo-microarrays (Agilent technologies, PN G4122F) for 17 hours at $65^{\circ} \mathrm{C}$. Microarrays were scanned using a dynamic auto focus microarray scanner (Agilent technology). Raw data were normalised using local background subtraction and local Lowess dye normalisation. Data were analysed using Rosetta Resolver Gene Expression Analysis System v6.0 (Rosetta Inpharmatics LLC, Seattle, WA). Dye-swap replicates were precombined before any statistical analysis. For each group, statistically significant regulated sequences were defined as the sequences whose expression in the $\mathrm{db} /+$ or in the RSG-treated $\mathrm{db} / \mathrm{db}$ samples was statistically different from the expression in the untreated 
$\mathrm{db} / \mathrm{db}$ (reference), as calculated by Rosetta error-weighted model [19]. For this study a $P$-value $<.001$ was considered to be significant, and a fold-change value cutoff was $\geq|1.3|$. Ingenuity Pathway Analysis application (Ingenuity Systems, CA, USA) was used to allow functional interpretation of the data. Promoter gene sequences were investigated for the presence of proximal ( $\sim 500 \mathrm{bp}$ from initiation site) PPAR response element (PPRE) in their promoters with MatInspector (Genomatix; GmbH) [20]. The partial leastsquares (PLSs) projection to latent structure analysis [21] was performed using Simca-P12 software (Umetrics, Umea, Sweden).

2.5. Real-Time RT-PCR. Total RNA $(1 \mu \mathrm{g})$ from each animal ( $n=6$ /group) and from pooled reference $\mathrm{db} / \mathrm{db}$ was reverse transcribed into cDNA using a transcription kit (Applied Biosystems, PN 4368813). PCR reactions were then proceeded in microfluidic cards using the ABI PRISM 7900HT Sequence Detection System (Applied Biosystems). Each microfluidic card was preloaded with predesigned Taqman probes and primers for genes and RNA $18 \mathrm{~S}$ reference gene. cDNA (100 ng) was mixed with 2X Taqman Universal PCR master Mix (Applied Biosystems, PN 4324020) and loaded in each well $(n=3)$. The following temperature profile was used: $10 \mathrm{~min}$ at $94.5^{\circ} \mathrm{C}$, followed by 40 cycles of $97^{\circ} \mathrm{C}$ for $30 \mathrm{sec}$ and $59.7^{\circ} \mathrm{C}$ for $1 \mathrm{~min}$. Normalised data with RNA $18 \mathrm{~S}$ were analysed using the threshold cycle $(\mathrm{Ct})$ relative quantification method [22], and the $\Delta \Delta \mathrm{Ct}$ method was used to compare the amounts of RNA in test and reference groups.

2.6. Immunocytochemistry. Adipose tissue was fixed in $4 \%$ neutral buffered formaldehyde, and cryostat sections of $7 \mu \mathrm{m}$ were prepared. The labelling was performed using a Discovery XT automat (Ventana Medical Systems, Tucson, USA). Sections were incubated $1 \mathrm{~h} 30$ at $37^{\circ} \mathrm{C}$ with Alexa fluor 488-conjugated anti-OxPhos Complex IV subunit I antibody (1/100 dilution, Molecular Probes, PN A21296). Immunolabelling was visualized and imaged using an LSM 510 confocal microscope (Carl Zeiss SAS, France).

\section{Results}

3.1. Effects of RSG on Physiological Characteristics. At the beginning of the experiment the RSG-treated and control $\mathrm{db} / \mathrm{db}$ groups of mice were comparably obese and diabetic. Blood glucose concentrations and body weights for these two groups were similar and were both significantly different from $\mathrm{db} /+$ nondiabetic mice (Table 1 ). Eighteen days of dose-dependent treatment with RSG resulted in a reversion of hyperglycaemia. Indeed, a reduction of blood glucose concentrations and $\mathrm{HbAlc}$ were observed for all RSG doses tested. Blood glucose normalisation was obtained from $30 \mathrm{mg} / \mathrm{kg}(0.98 \pm 0.12$ versus $1.1 \pm 0.1 \mathrm{~g} / \mathrm{L}$ in $\mathrm{db} /+$ ); HbAlc levels from $\mathrm{db} / \mathrm{db}$-treated mice were all significantly above the $\mathrm{db} /+$ control mice, showing only a partial normalisation of this parameter (Table 1).
3.2. Targeted Metabolomic Assessment of Plasma and Tissue Lipids. Diabetic $\mathrm{db} / \mathrm{db}$ mice displayed higher plasma trioleate concentrations than $\mathrm{db} /+$. RSG-treated $\mathrm{db} / \mathrm{db}$ mice showed a clear decrease in the levels of the two principal plasma TGs, trilinoleate and trioleate. When compared to $\mathrm{db} /+$, TG normalisation was achieved from $10 \mathrm{mg} / \mathrm{kg}$ RSG treatment $(16.8 \pm 6.5$ versus $26.8 \pm 10.2 \mathrm{nmol} / \mathrm{mL}$ and $6.7 \pm$ 1.6 versus $11.8 \pm 3.4 \mathrm{nmol} / \mathrm{mL}$ for trilinoleate and trioleate, respectively). Plasma FFA concentrations showed a tendency to be higher in $d b / d b$ than $d b /+$ mice, but the difference remained significant only for linoleic acid. RSG treatment further decreased plasma FFA concentrations compared to both $\mathrm{db} / \mathrm{db}$ and $\mathrm{db} /+$, but in this latter case it did not achieve the significance threshold (Table 1).

In the liver of diabetic $\mathrm{db} / \mathrm{db}$ mice, both TG and FFA levels reached a higher concentration compared to $\mathrm{db} /+$. From $10 \mathrm{mg} / \mathrm{kg}$ the RSG treatment of $\mathrm{db} / \mathrm{db}$ further increased trioleate and oleic and palmitic acids. In parallel, the liver weight of RSG-treated $\mathrm{db} / \mathrm{db}$ mice increased $(+86 \%,+64 \%$, and $+46 \%$ at 10,30 , and $100 \mathrm{mg} / \mathrm{kg}$ RSG, resp.) versus the control db/db mice.

As expected, IAT weight was higher in both RSG-treated and control $\mathrm{db} / \mathrm{db}$ mice compared to the $\mathrm{db} /+$ mice $(2.10 \pm$ 0.06 in untreated $\mathrm{db} / \mathrm{db}$ mice; $1.99 \pm 0.11,2.09 \pm 0.13$, and $2.16 \pm 0.09 \mathrm{~g}$ in treated $\mathrm{db} / \mathrm{db}$ mice at 10,30 , and $100 \mathrm{mg} / \mathrm{kg}$ $\mathrm{RSG}$, respectively versus $0.17 \pm 0.02 \mathrm{~g}$ in $\mathrm{db} /+$ mice). In contrast, the TG concentrations relative to adipose tissue mass in $\mathrm{db} /+$ were markedly higher than in RSG-treated or untreated $\mathrm{db} / \mathrm{db}$. FFA adipose tissue concentrations remained basically unchanged either between $\mathrm{db} / \mathrm{db}$ and $\mathrm{db} /+$ or following RSG treatment except for oleic acid the levels of which in $\mathrm{db} / \mathrm{db}$ with or without RSG treatment far exceeded those of $\mathrm{db} /+$.

Soleus muscle weight was unaltered by both pathology and treatment (Table 1), although fat accumulation was observed for control db/db versus RSG-treated $\mathrm{db} / \mathrm{db}$ during the soleus muscle dissection.

3.3. Transcriptomic Profile of the Insulin-Sensitive Tissues of $d b /+$ and RSG-Treated $d b / d b$. Changes in global gene expression were assessed in three insulin-sensitive tissues, liver, IAT, and soleus muscle, involved in glucose and lipid metabolism using whole-mouse genome microarrays. Differences in gene expression between $\mathrm{db} /+$ or RSG-treated $\mathrm{db} / \mathrm{db}$ versus the control $\mathrm{db} / \mathrm{db}$ group were filtered according to a $P$-value $<.001$ and a fold change $\geq|1.3|$ (Rosetta error- weighted model [19]). One gene could be represented by different gene (probes) sequences. Gene alteration between nondiabetic $\mathrm{db} /+$ versus diabetic $\mathrm{db} / \mathrm{db}$ mice (see Supplementary Table 1 in material available online at doi: 10.1155/2010/679184) was determined in the liver (6539 regulated sequences), in the soleus muscle (7895 regulated sequences), and in the IAT (13207 regulated sequences). RSG treatment of $\mathrm{db} / \mathrm{db}$ mice elicited significant changes in the expression of a comparable number of genes to that observed between $\mathrm{db} /+$ and the diabetic control $\mathrm{db} / \mathrm{db}$ reference group, namely in the liver (5567, 4788, and 4549 regulated sequences at 10, 30, and $100 \mathrm{mg} / \mathrm{kg}$ RSG, resp.), in the IAT (5710, 9005, and 10335 
TABLE 1: Animal characteristics, blood and tissue analysis: $\mathrm{db} / \mathrm{db}$ were compared by Student's “ $t$ " test versus $\mathrm{db}^{+},{ }^{\#} P<.05$; ${ }^{\# \#} P<.01 ;{ }^{\# \#} P<$ .001 . RSG-treated groups were compared by ANOVA and Dunnett test versus untreated $\mathrm{db} / \mathrm{db}, * P<.05 ; * * P<.01 ; * * * P<.001$, or versus $\mathrm{db} /+,{ }^{\dagger} P<.05 ;{ }^{\dagger \dagger} P<.01 ;{ }^{\dagger \dagger} P<.001 . n=6$ animals otherwise specified.

\begin{tabular}{|c|c|c|c|c|c|}
\hline \multirow[b]{2}{*}{ Parameters (units) } & \multicolumn{4}{|c|}{$\mathrm{db} / \mathrm{db}$} & \multirow{2}{*}{$\begin{array}{c}\mathrm{db} /+ \\
\text { Untreated }\end{array}$} \\
\hline & Untreated & RSG $10 \mathrm{mg} / \mathrm{kg}$ & RSG $30 \mathrm{mg} / \mathrm{kg}$ & RSG $100 \mathrm{mg} / \mathrm{kg}$ & \\
\hline Body weight $0 \mathrm{~d}$ & $38.9 \pm 0.4^{\# \# \#}$ & $39.4 \pm 0.6$ & $39.8 \pm 0.7$ & $39.5 \pm 1.1$ & $24.6 \pm 0.7$ \\
\hline Body weight $(\mathrm{g}) 18 \mathrm{~d}$ & $40.6 \pm 0.7^{\# \# \#}$ & $46.2 \pm 0.9^{* *}$ & $47.8 \pm 0.6^{* * *}$ & $46.8 \pm 2.1^{* *}$ & $25.9 \pm 0.4$ \\
\hline Liver weight (g) & $1.75 \pm 0.03^{\# \# \#}$ & $3.25 \pm 0.17^{* * *+\dagger \dagger}$ & $2.83 \pm 0.20^{* *+\dagger \dagger}$ & $2.47 \pm 0.27^{* \dagger \dagger}$ & $1.37 \pm 0.05$ \\
\hline Inguinal Adipose weight (g) & $2.09 \pm 0.06^{\# \# \#}$ & $1.99 \pm 0.11^{\dagger \dagger \dagger}$ & $2.09 \pm 0.13^{\dagger \dagger \dagger}$ & $2.16 \pm 0.09^{\dagger \dagger \dagger}$ & $0.17 \pm 0.02$ \\
\hline Soleus muscle weight (mg) & $6.67 \pm 1.33$ & $6.00 \pm 0.85$ & $5.05 \pm 0.5$ & $4.79 \pm 0.36$ & $6.13 \pm 1.82$ \\
\hline Blood Glucose $(\mathrm{mmol} / \mathrm{l})$ 0d & $16.9 \pm 1.3^{\# \# \#}$ & $16.3 \pm 1.3^{\dagger \dagger \dagger}$ & $15.8 \pm 0.9^{\dagger \dagger \dagger}$ & $16.4 \pm 1.1^{\dagger \dagger \dagger}$ & $5.8 \pm 0.4$ \\
\hline Blood Glucose (mmol/l) 18d & $15.1 \pm 0.9^{\# \# \#}$ & $8.0 \pm 0.7^{* * * \dagger \dagger}$ & $5.4 \pm 0.6^{* * *}$ & $4.1 \pm 0.5^{* * *}$ & $5.1 \pm 0.5$ \\
\hline HbAlc \% & $7.14 \pm 0.28^{\# \# \#}$ & $6.16 \pm 0.34^{\dagger \dagger \dagger}$ & $5.76 \pm 0.32 * * \dagger \dagger \dagger$ & $5.52 \pm 0.23^{* * \dagger \dagger \dagger}$ & $3.61 \pm 0.13$ \\
\hline \multicolumn{6}{|c|}{ Plasmatic triglycerides $(\mathrm{nmol} / \mathrm{mL})$} \\
\hline Trilinoleate $(n=3-5)$ & $49.6 \pm 2.3$ & $16.8 \pm 6.5^{* * *}$ & $10.2 \pm 3.0^{* * *}$ & $23.2 \pm 5.4^{* *}$ & $26.8 \pm 10.2$ \\
\hline Trioleate $(n=3-5)$ & $19.7 \pm 1.4^{\#}$ & $6.7 \pm 1.6^{* * *}$ & $3.2 \pm 0.9^{* * *}$ & $8.0 \pm 2.5^{* * *}$ & $11.8 \pm 3.4$ \\
\hline \multicolumn{6}{|l|}{ Plasmatic FFA (nmol/mL) } \\
\hline Palmitic acid & $91.8 \pm 5.5$ & $70.4 \pm 7.0$ & $51.4 \pm 7.8^{* * *}$ & $64.9 \pm 7.0^{*}$ & $85.9 \pm 10.5$ \\
\hline Linoleic acid & $83.8 \pm 4.5^{\#}$ & $70.5 \pm 6.0$ & $43.0 \pm 10.2^{*}$ & $54.5 \pm 12.7$ & $65.3 \pm 4.4$ \\
\hline Oleic acid & $91.1 \pm 12.0$ & $72.1 \pm 5.4$ & $38.4 \pm 12.1^{* *}$ & $47.4 \pm 13^{*}$ & $70.2 \pm 8.9$ \\
\hline \multicolumn{6}{|l|}{ Liver triglycerides (nmol/g) } \\
\hline Trilinoleate & $116 \pm 24^{\# \#}$ & $76.0 \pm 21.9^{\dagger}$ & $43.2 \pm 8.9^{*}$ & $33.5 \pm 4.4^{* *}$ & $20.0 \pm 3.9$ \\
\hline Trioleate & $1033 \pm 314^{\#}$ & $10240 \pm 1489^{* * *+\dagger \dagger}$ & $7746 \pm 1603^{* *+\dagger \dagger}$ & $2708 \pm 846$ & $59 \pm 13$ \\
\hline \multicolumn{6}{|l|}{ Liver FFA (nmol/g) } \\
\hline Palmitic acid & $481 \pm 49$ & $583 \pm 43^{\dagger \dagger}$ & $573 \pm 47^{\dagger}$ & $702 \pm 67^{* *+\dagger \dagger}$ & $366 \pm 13$ \\
\hline Linoleic acid & $289 \pm 27^{\#}$ & $236 \pm 7$ & $253 \pm 17$ & $331 \pm 46^{\dagger \dagger}$ & $209 \pm 11$ \\
\hline Oleic acid & $484 \pm 87^{\#}$ & $1031 \pm 110^{* *+十 \dagger}$ & $997 \pm 82^{* * \dagger+\dagger}$ & $945 \pm 148^{* \dagger \dagger \dagger}$ & $186 \pm 18$ \\
\hline \multicolumn{6}{|l|}{ IAT triglycerides (nmol/g) } \\
\hline Trilinoleate & $5965 \pm 2373$ & $3670 \pm 1177^{\dagger \dagger}$ & $5343 \pm 1542^{\dagger}$ & $4118 \pm 674^{\dagger}$ & $15524 \pm 4320$ \\
\hline Trioleate & $7766 \pm 1962$ & $6515 \pm 2729$ & $15382 \pm 5458$ & $11836 \pm 3059$ & $16016 \pm 5333$ \\
\hline \multicolumn{6}{|l|}{ IAT FFA (nmol/g) } \\
\hline Palmitic acid & $236 \pm 61$ & $265 \pm 24$ & $302 \pm 67$ & $462 \pm 36^{*}$ & $424 \pm 92$ \\
\hline Linoleic acid & $329 \pm 53^{\#}$ & $328 \pm 25$ & $454 \pm 97$ & $570 \pm 57^{*}$ & $558 \pm 81$ \\
\hline Oleic acid & $281 \pm 48^{\# \#}$ & $310 \pm 32^{\dagger}$ & $416 \pm 110^{\dagger \dagger}$ & $514 \pm 56^{\dagger \dagger}$ & $65 \pm 10$ \\
\hline
\end{tabular}

regulated sequences at 10,30 , and $100 \mathrm{mg} / \mathrm{kg}$ RSG, resp.), and in the soleus muscle $(3413,3644$, and 3620 regulated sequences at 10, 30, and $100 \mathrm{mg} / \mathrm{kg}$ RSG, resp.).

3.4. Functional Interpretation of the Changes in Transcriptomic Profiles. To interpret the biological alteration, differentially expressed genes $(\mathrm{db} /+$ or RSG-treated $\mathrm{db} / \mathrm{db}$ versus control $\mathrm{db} / \mathrm{db}$ reference group, Supplemental Table 1) with known gene symbol (HUGO) were submitted to Ingenuity Pathway analysis. Each gene symbol was mapped to its corresponding gene in the Ingenuity Pathways Knowledge database, and biological functions and diseases were assigned to the pattern of gene expression. Functions were listed from most significant to least, and the horizontal line shows the cutoff value for significance $(P<.05$, adjusted BenjaminiHochberg; Supplemental Figure 1). As expected, either in the nondiabetic $\mathrm{db} /+$ (diabetes effect given as reciprocal $(\mathrm{db} /+$ versus $\mathrm{db} / \mathrm{db})$, see below) or in the RSG-treated $\mathrm{db} / \mathrm{db}$ mice, the changes in expression mainly involved genes related to lipid and carbohydrate metabolism not only in the liver but also in the IAT and the soleus muscle (Supplemental Figure 1). Moreover, groups of genes were also enriched in several functions related to cell signalling, movement, or development in liver, adipose tissue, and soleus muscle. These results could be explained by diabetesinduced morphological and/or growth alteration of hepatocytes, adipocytes, and myocytes in $\mathrm{db} / \mathrm{db}$ mice as well as in $\mathrm{db} / \mathrm{db}$ under RSG treatment. However, in the attempt to link transcriptomic and metabolomic data we focussed our study on genes involved in lipid and carbohydrate metabolism and potentially associated with diabetes. This list included 506 gene sequences involved in glycolysis, gluconeogenesis, TG and FFA metabolism, and pentose phosphate synthesis, as well as genes involved in mitochondrial functions, that is, $\beta$-oxidation, citrate cycle, and oxidative phosphorylation. Thereafter, to facilitate direct comparison with RSG treatment effect, we used the reciprocal form of the diabetes 
TABLE 2: Model parameters from multivariate analysis (PLS) based on liver, IAT and muscle gene expression. $\mathrm{R}^{2} \mathrm{X}$ : \% of variation of $\mathrm{X}$ that explained Y; $R^{2}$ Ycum: \% of variation of Y explained by the model; $Q^{2}{ }_{Y c u m}$ : \% of variation of Y predicted by the model. Cum are for all PLS components.

\begin{tabular}{|c|c|c|c|c|c|}
\hline & PLS component & $\mathrm{R}^{2} \mathrm{X}($ cum $)$ & $\mathrm{R}^{2} \mathrm{Y}(\mathrm{cum})$ & $\mathrm{Q}^{2}$ (cum) & $P$-value \\
\hline \multicolumn{6}{|l|}{ Liver } \\
\hline $\begin{array}{l}\text { Oleic } 275 \text { gene } \\
\text { sequences }\end{array}$ & 1 & 0.67 & 0.78 & 0.76 & $3.06 \mathrm{E}-07$ \\
\hline $\begin{array}{l}\text { Oleic } 40 \text {-top gene } \\
\text { sequences }\end{array}$ & 1 & 0.94 & 0.80 & 0.80 & $5.00 \mathrm{E}-08$ \\
\hline $\begin{array}{l}\text { Trioleate } 275 \text { gene } \\
\text { sequences }\end{array}$ & 2 & 0.74 & 0.86 & 0.80 & $3.11 \mathrm{E}-06$ \\
\hline $\begin{array}{l}\text { Trioleate } 40 \text {-top } \\
\text { gene sequences }\end{array}$ & 2 & 0.72 & 0.89 & 0.85 & $2.30 \mathrm{E}-07$ \\
\hline $\begin{array}{l}\text { Weight } 275 \text { gene } \\
\text { sequences }\end{array}$ & 2 & 0.77 & 0.96 & 0.95 & $4.92 \mathrm{E}-11$ \\
\hline $\begin{array}{l}\text { Weight } 40 \text {-top } \\
\text { gene sequences }\end{array}$ & 1 & 0.75 & 0.96 & 0.93 & $1.80 \mathrm{E}-14$ \\
\hline \multicolumn{6}{|l|}{ Liver+IAT+Soleus } \\
\hline $\begin{array}{l}\text { Glycemia } 846 \text { gene } \\
\text { sequences }\end{array}$ & 4 & 0.71 & 0.94 & 0.73 & $1.00 \mathrm{E}+00$ \\
\hline $\begin{array}{l}\text { Glycemia } 40 \text {-top } \\
\text { gene sequences }\end{array}$ & 3 & 0.86 & 0.84 & 0.68 & 7.00E-03 \\
\hline
\end{tabular}

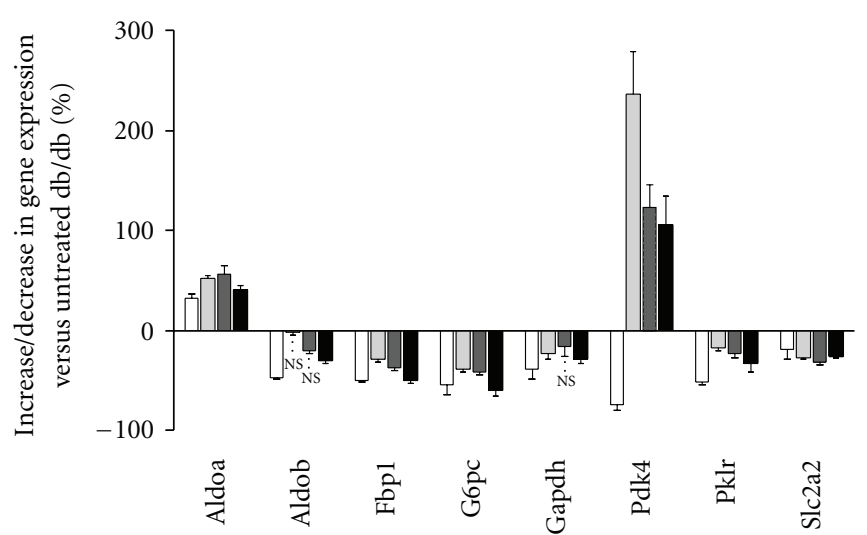

(a)

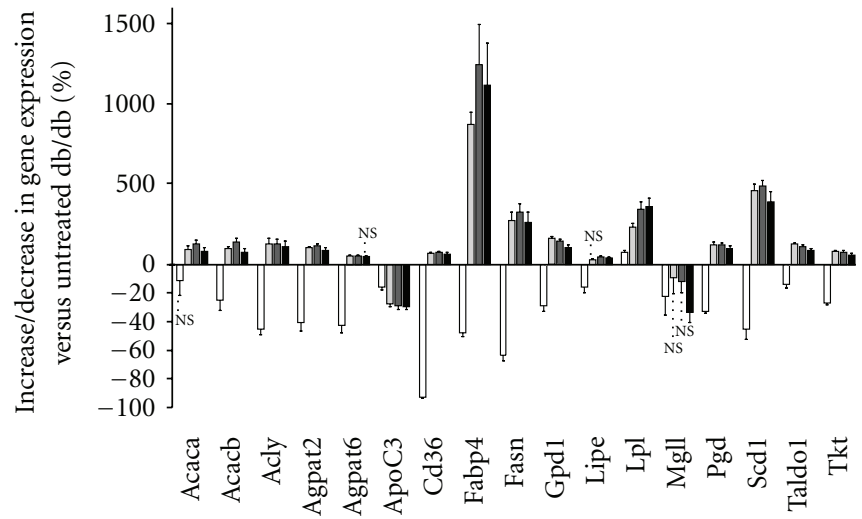

(b)

Figure 1: Expression profiles of key genes involved in liver glucose and lipid metabolism. Differentially expressed genes in $\mathrm{db} /+(\mathrm{the}$ white square) as well as 10 (the off-white square), 30 (the grey square), and 100 (the black square) mg/kg RSG-treated db/db mice were measured versus untreated $\mathrm{db} / \mathrm{db}$ and plotted as the mean (\% increase/decrease of $\mathrm{db} / \mathrm{db}$ control) \pm SEM $(n=6)$. NS; $P \geq .001$ otherwise $P<.001$. (a) Genes related to glucose metabolism: Aldoa, Aldob, aldolase 1A, 2B; Fbp1, fructose bisphosphatase 1; G6pc, glucose-6-phosphatase, catalytic; Gapdh, glyceraldehyde-3-phosphate dehydrogenase; Pdk4, pyruvate dehydrogenase kinase, isoenzyme 4; Pklr, pyruvate kinase liver and red blood cell; Slc2a2, solute carrier family 2 (facilitated glucose transporter), member 2. (b) Genes related to FA transport, FA and TG synthesis, and pentose pathway: Acaca, Acacb, acetyl-Coenzyme A carboxylase alpha, beta; Acly, ATP citrate lyase; Agpat2, Agpat6, 1-acylglycerol-3phosphate O-acyltransferase 2, 6; Apoc3, apolipoprotein C-III; Cd36, CD36 antigen; Fabp2, fatty acid-binding protein 2, intestinal; Fabp4, fatty acid-binding protein 4, adipocyte; Fasn, fatty acid synthase; Gpd1, glycerol-3-phosphate dehydrogenase 1 (soluble); Lpl, lipoprotein lipase; Mgll, monoglyceride lipase; Pgd, phosphogluconate dehydrogenase; Scd1, stearoyl-Coenzyme A desaturase 1; Taldo1, transaldolase 1; Tkt, transketolase.

effect, that is, untreated nondiabetic $\mathrm{db} /+$ versus diabetic mice $\mathrm{db} / \mathrm{db}$. Consequently, RSG-induced normalisation of gene expression is defined as genes that were significantly changed by RSG (RSG-treated $\mathrm{db} / \mathrm{db}$ versus $\mathrm{db} / \mathrm{db}$ ) in the same direction as nondiabetic $(\mathrm{db} /+$ versus $\mathrm{db} / \mathrm{db})$ mice.
3.5. Effect of RSG on the Liver Metabolic-Related $m R N A$ Expression. In the liver among the 506 gene sequences 276 were differentially expressed in either $\mathrm{db} /+$ versus $\mathrm{db} / \mathrm{db}$ (Supplemental Table 2) or RSG-treated $\mathrm{db} / \mathrm{db}$ versus $\mathrm{db} / \mathrm{db}$. Supplemental Figure 2(a) displays the microarray 


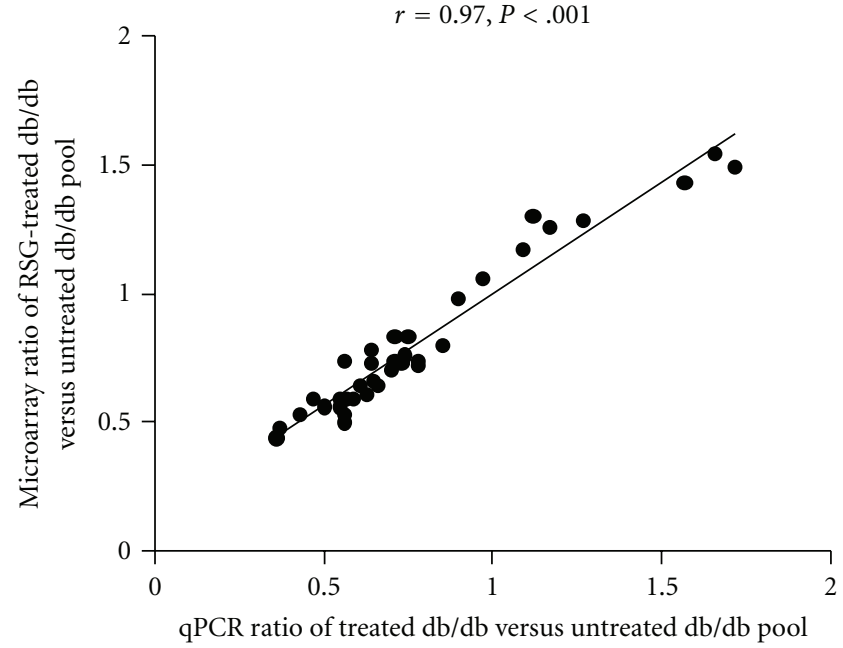

(a)

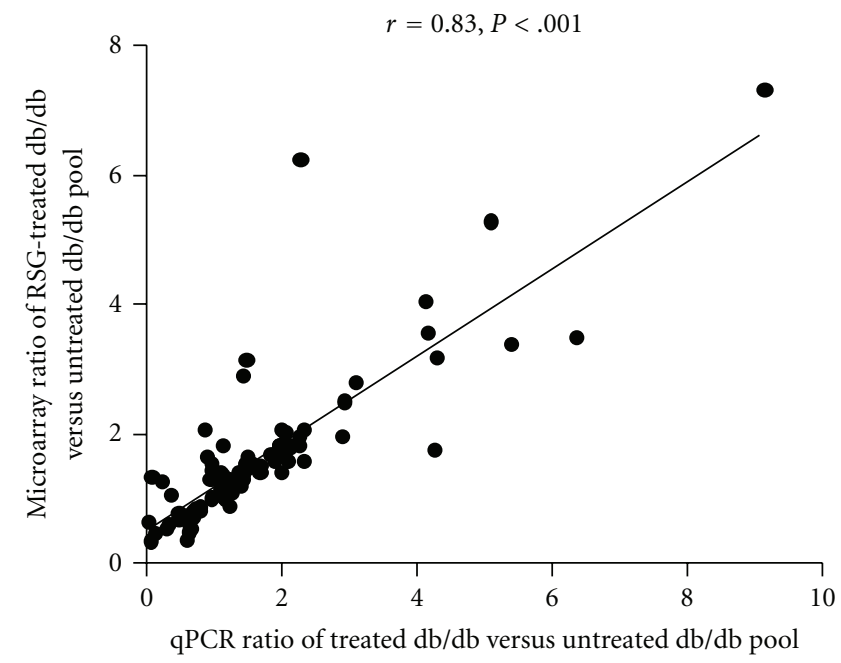

(c)



(b)

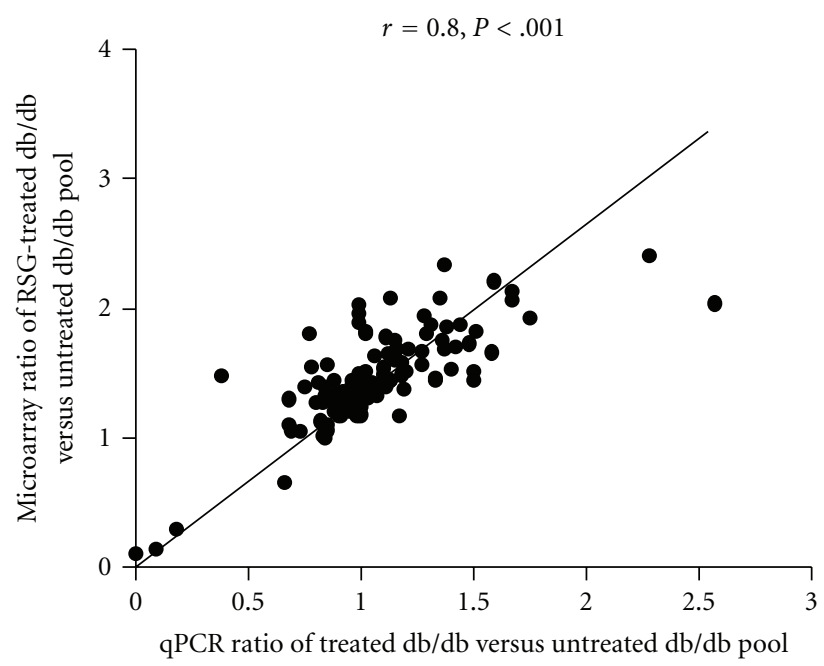

(d)

Figure 2: Correlation plot between microarray and qPCR data. Genes involved in (a) liver carbohydrate metabolism, (b) liver FA and TG metabolism, (c) IAT FA and TG metabolism, and (d) IAT citrate cycle and oxidative phosphorylation. Microarray ratio of differentially expressed genes in $\mathrm{db} /+$ and RSG-treated $\mathrm{db} / \mathrm{db}$ versus untreated $\mathrm{db} / \mathrm{db}$ mice were plotted on the $y$-axis and qPCR ratio data on the $x$-axis. Correlations were assessed using Pearson's correlation coefficient $(r)$ and $P$-value $<.001$.

data overview of differentially expressed genes between lean $\mathrm{db} /+$ or RSG-treated mice and the diabetic $\mathrm{db} / \mathrm{db}$ strain involved in glucose metabolism. As shown in Figure 1(a), remarkably, RSG treatment resulted in a partial or complete normalisation in mRNA expression of genes encoding for glycolysis/gluconeogenesis key enzymes such as Glut2, Gapdh, Pklr or Fbp1, and G6pc. These effects were particularly pronounced at $100 \mathrm{mg} / \mathrm{kg}$ of RSG. The only exception is Pdk4 mRNA expression which is downregulated in $\mathrm{db} /+$ mice but increased in RSG-treated $\mathrm{db} / \mathrm{db}$ mice when compared to the control db/db. Real-time PCR was used to confirm the differential expression of genes involved in glucose metabolism (Supplemental Table 3). Figure 2(a) shows that microarray ratio measurements were strongly correlated to that obtained by PCR $(r=0.97 ; P<.001$; number of xy pairs $=23$ ).
Contrary to gluconeogenesis-related genes, which seemed to be normalised by RSG treatment, microarray data overview shows that a large number of genes involved in lipid metabolism was regulated in the opposite direction to $\mathrm{db} /+$ (Supplemental Figures 2(b) and 1(b)). This included genes that were downregulated in $\mathrm{db} /+$ but were all markedly upregulated in RSG-treated mice when compared to $\mathrm{db} / \mathrm{db}$. For example, at $10 \mathrm{mg} / \mathrm{kg}$ RSG-mediated upregulation of genes implicated in lipid metabolism synthesis (Figure 1(b)), such as the lipid transporters $\operatorname{Cd} 36(+62 \%, P<.001)$, the fatty acid binding protein Fabp4 $(+870 \%, P<.001)$, the key enzymes in FFA and TG synthesis such as the ATP citrate lyase (Acly, $+124 \%, P<.001$ ), the acetyl-CoA-carboxylase (Acaca, $+87 \%, P<.001$ ), the fatty acid synthase (FAS, $+270 \%, P<.001)$, and the stearoyl-Coenzyme A desaturase (Scd1 $+455 \%, P<.001)$ or was involved in the pentose 

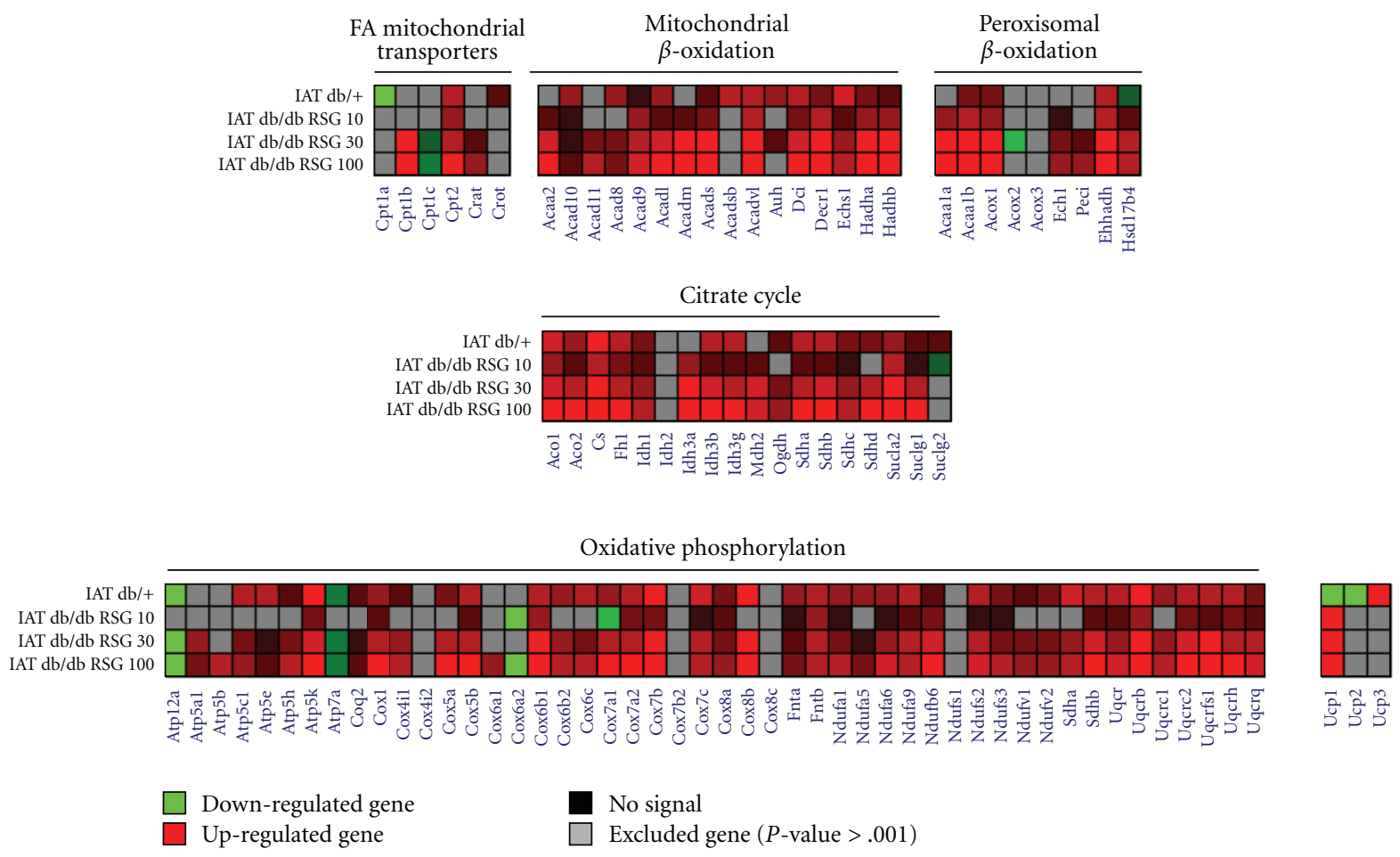

FIgURE 3: Two-dimensional representation of differentially expressed genes involved in IAT mitochondrial and peroxisomal functions. Ratio for differentially expressed genes in $\mathrm{db} /+$ and RSG-treated $\mathrm{db} / \mathrm{db}$ versus untreated $\mathrm{db} / \mathrm{db}$ were plotted. Each coloured box represents differential expression ratio ranging from bright green (lowest) to bright red (highest). Missing value are in grey when $P$-value $\geq .001$. Genes involved in mitochondrial transport of FA, in mitochondrial and peroxisomal $\beta$-oxidation and citrate cycle and in oxidative phosphorylation were shown.

phosphate pathway such as the transketolase (Tkt, $+74 \%$, $P<.001)$ and phosphogluconate dehydrogenase (Pgd, $+117 \%, P<.001)$. All these results were confirmed by realtime qPCR with a very strong correlation (Supplemental Table 3 and Figure 2(b); $r=0.94, P<.001$; number of xy pairs $=155)$. The increased expression of genes encoding lipogenic enzymes and the pentose phosphate pathway could account for the increase in liver TG, FFA content, and weight liver (Table 1).

\subsection{Effect of RSG on IAT Metabolic-Related mRNA Expression.} In adipose tissue, among the 506 gene sequences 391 were differentially expressed in either $\mathrm{db} /+$ versus $\mathrm{db} / \mathrm{db}$ or RSG-treated $\mathrm{db} / \mathrm{db}$ versus $\mathrm{db} / \mathrm{db}$ (Supplemental Table 2). Numerous upregulated genes in $d b /+$ or RSG-treated $\mathrm{db} / \mathrm{db}$ relative to $\mathrm{db} / \mathrm{db}$ diabetic mice (Supplemental Figure 3 and Figure 3 ) potentially stimulate lipid metabolism and mitochondrial functions.

Contrary to the liver, RSG treatment in IAT regulated the majority of metabolism-related genes in the same direction as observed in $\mathrm{db} /+$ mice when compared to $\mathrm{db} / \mathrm{db}$. Indeed, genes involved in glucose metabolism, FFA and TG metabolism, pentose phosphate synthesis, and mitochondrial function were upregulated and/or normalised by RSG-treatment, some of them with a clear dose effect (Figures 4(a), 4(b), 4(c)). RSG treatment (10-100 mg/kg) partially normalised mRNA expression (Figure 4(a)) of two key genes involved in glucose metabolism such as the glucose transporter Glut4 (Slc2a4, $+45 \%, P<.001$ in $30 \mathrm{mg} / \mathrm{kg}$ RSG group and $+114 \%, P<.001$ in $\mathrm{db} /+$ group) and the pyruvate dehydrogenase kinase 4 the downregulation of which stimulates glucose metabolism (Pdk4, 37\%, $P<.001$ in $30 \mathrm{mg} / \mathrm{kg}$ RSG group and no change in $\mathrm{db} /+$ group). On one hand, we observed partial normalisation of genes encoding FFA or TG metabolic enzymes including Acaca $(+163 \%$, in $30 \mathrm{mg} / \mathrm{kg}$ RSG group and $+474 \%$, in $\mathrm{db} /+$ group, $P<.001)$ and Fasn $(+240 \%$, in $30 \mathrm{mg} / \mathrm{kg}$ RSG group and $+674 \%$, in $\mathrm{db} /+$ group, $P<.001)$ or the pentose phosphate pathway gene Tkt $(+86 \%$, in $30 \mathrm{mg} / \mathrm{kg}$ RSG group and $+409 \%$ in $\mathrm{db} /+$ group, $P<.001$ ) (Figure $4(\mathrm{a})$ ). On the other hand, for almost all genes involved in mitochondrial $\beta$-oxidation, citrate cycle, and oxidative phosphorylation, the level of upregulated genes observed in RSG-treated mice far exceeded that of $\mathrm{db} /+$ regulated genes (Figures $4(\mathrm{~b}), 4(\mathrm{c})$ ). All these results were validated with qPCR technique with strong correlation (Supplemental Table 3 and Figure 2(c); $r=0.83, P<.001$; number of xy pairs = 96; Figure $2(d)$; $r=0.80, P<.001$; number of xy pairs $=156)$.

3.7. Mitochondrial Renewal in db/db IAT Treated with RSG. The gene expression changes observed in adipose tissue suggested a mitochondrial dysfunction in $\mathrm{db} / \mathrm{db}$ diabetic mice, but the RSG treatment appears to normalise a part of these alterations. To test whether diabetes and RSG 


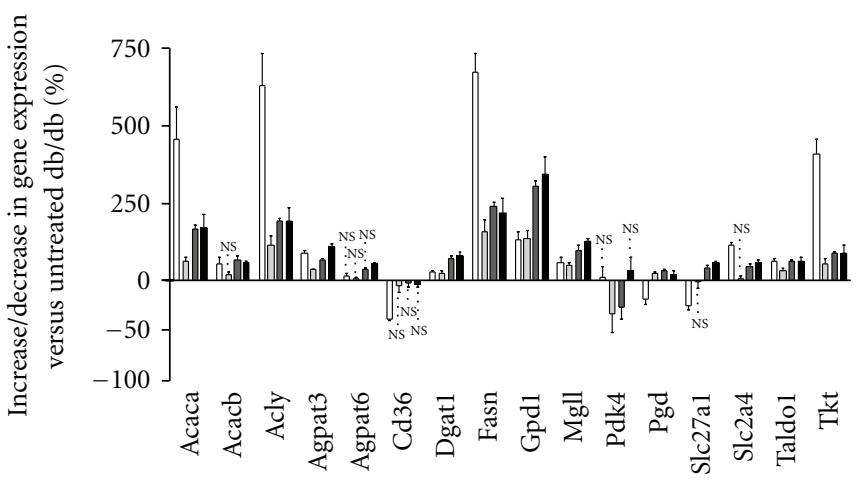

(a)

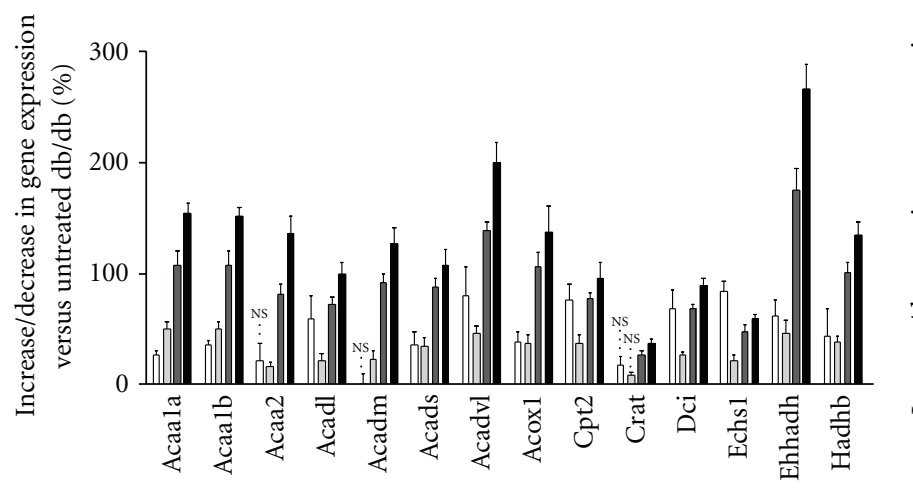

(b)

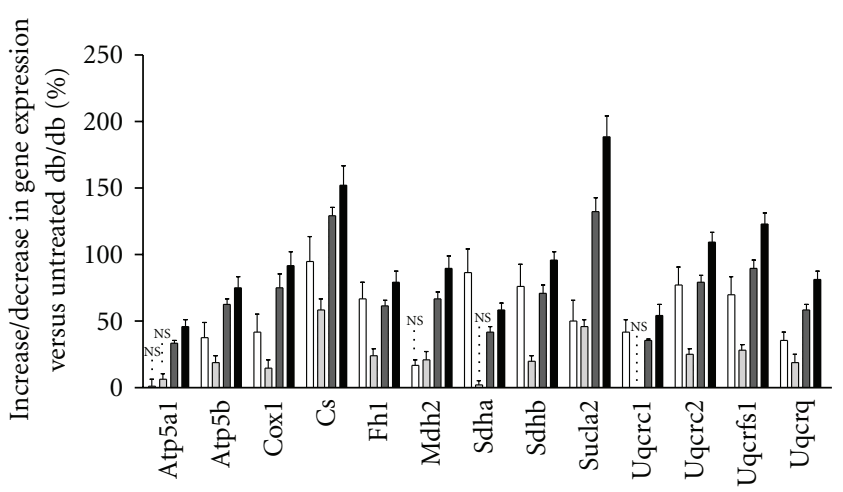

(c)

FIGURE 4: Expression profiles of key genes involved in IAT FA metabolism. Differentially expressed genes in db/+ (the white square) as well as 10 (the off-white square), 30 (the grey square), and 100 (the black square) mg/kg RSG-treated db/db mice were measured versus untreated $\mathrm{db} / \mathrm{db}$ and plotted as the mean (\% increase/decrease of $\mathrm{db} / \mathrm{db}$ control) $\pm \mathrm{SEM}(n=6)$. NS; $P \geq .001$ otherwise $P<.001$. (a) Genes related to FA transport, glucose, FA and TG synthesis and pentose pathway*: Agpat3, 1-acylglycerol-3-phosphate O-acyltransferase 3; Dgat1, diacylglycerol O-acyltransferase 1; Slc27a1, solute carrier family 27 (fatty acid transporter), member 1; Slc2a4, solute carrier family 2 (facilitated glucose transporter), member 4. (b) Genes related to mitochondrial and peroxisomal $\beta$-oxidation: Acaala, Acaa1b, acetyl-Coenzyme A acyltransferase 1A, 1B; Acaa2, acetyl-Coenzyme A acyltransferase 2; Acadl, acyl-Coenzyme A dehydrogenase, long chain; Acadm, acyl-Coenzyme A dehydrogenase, medium chain; Acads, acyl-Coenzyme A dehydrogenase, short chain; Acadvl, acylCoenzyme A dehydrogenase, very long chain; Acox1, acyl-Coenzyme A oxidase 1, palmitoyl; Cpt2, carnitine palmitoyltransferase 2; Crat, carnitine acetyltransferase; Dci, dodecenoyl-Coenzyme A delta isomerase (3,2 trans-enoyl-Coenzyme A isomerase); Echs1, enoyl-Coenzyme A hydratase, short chain 1 mitochondrial; Ehhadh, enoyl-Coenzyme A, hydratase/3-hydroxyacyl-Coenzyme A dehydrogenase; Hadhb, hydroxyacyl-Coenzyme A dehydrogenase/3-ketoacyl-Coenzyme A thiolase/enoyl-Coenzyme A hydratase, beta subunit. (c) Genes related to citrate metabolism and oxidative phosphorylation: Atp5a1, ATP synthase, $\mathrm{H}+$ transporting, mitochondrial F1 complex, alpha subunit, isoform 1; Atp5b, ATP synthase, $\mathrm{H}+$ transporting mitochondrial F1 complex, beta subunit; Cox1, M. musculus mRNA for mitochondrial gene for subunit I of cytochrome c oxidase; Cs, citrate synthase; Fh1, fumarate hydratase 1; Mdh2, malate dehydrogenase 2, NAD (mitochondrial); Sdha, succinate dehydrogenase complex, subunit A, flavoprotein (Fp); Sdhb, succinate dehydrogenase complex, subunit B, iron sulfur (Ip); Sucla2, succinate-Coenzyme A ligase, ADP-forming, beta subunit; Uqcrc1, Uqcrc 2, ubiquinol-cytochrome c reductase core protein 1, 2; Uqcrfs1, ubiquinol-cytochrome c reductase, Rieske iron-sulfur polypeptide 1; Uqcrq, ubiquinol-cytochrome c reductase, complex III subunit VII. * gene abbreviations given in Figure 1 were not mentioned.

also affected mitochondrial biogenesis and functioning at cellular level, the mitochondrial content of adipocytes was determined by using a monoclonal antibody specific for OxPhos Complex IV subunit I (Cox1), a mitochondrial membrane-bound protein complex. We have compared control db/db versus $30 \mathrm{mg} / \mathrm{kg}$ RSG-treated $\mathrm{db} / \mathrm{db}$ adipocytes mitochondrial content, to avoid any possible side effects of the $100 \mathrm{mg} / \mathrm{kg}$ dose. As shown in Figure 5, signal intensity was stronger in adipocytes treated with RSG than in control $\mathrm{db} / \mathrm{db}$ diabetic mice $(P<.05)$. These results confirmed the transcriptional upregulation of Cox $1(+74 \%$; $P<.001)$ observed at $30 \mathrm{mg} / \mathrm{kg}$ dose and suggested that
RSG induced mitochondrial biogenesis in adipocytes, as previously described $[23,24]$.

\subsection{Effect of RSG on Metabolic-Related mRNA Expression in} Soleus Muscle. In soleus muscle among the 506 regulated gene sequences 186 were differentially expressed either in $\mathrm{db} /+$ versus $\mathrm{db} / \mathrm{db}$ or RSG-treated $\mathrm{db} / \mathrm{db}$ versus $\mathrm{db} / \mathrm{db}$ (Supplemental Table 2). Soleus muscle plays an important role in both carbohydrate and FFA metabolism. It is well established that in obesity there is a dysfunction in the capacity of skeletal muscles to store glycogen. Also, increased 


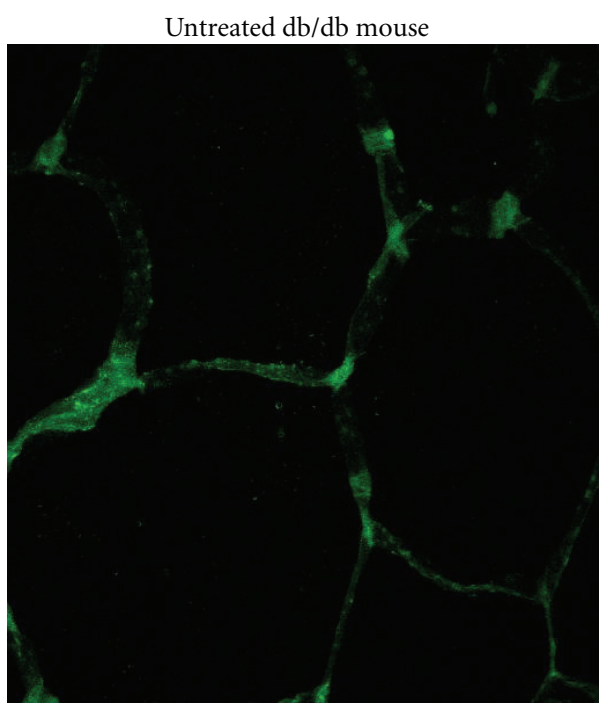

(a)



(b)

Figure 5: Immunochemical detection in $\mathrm{db} / \mathrm{db}$ and RSG-treated $\mathrm{db} / \mathrm{db}$ of the IAT OxPhos complex IV subunit I. IAT from untreated db/db (a) and from $30 \mathrm{mg} / \mathrm{kg} \mathrm{RSG-treated} \mathrm{db/db} \mathrm{(b)} \mathrm{were} \mathrm{isolated,} \mathrm{fixed} \mathrm{on} \mathrm{slide,} \mathrm{and} \mathrm{stained} \mathrm{with} \mathrm{anti-OxPhos} \mathrm{complex} \mathrm{IV} \mathrm{subunit} \mathrm{I.} \mathrm{Nuclei} \mathrm{were}$ identified with Hoechst 33342.

TG storage is positively correlated with markers of insulin resistance. Supplemental Figure 4 displayed microarray data overview of differentially expressed genes between lean $\mathrm{db} /+$ or RSG-treated $\mathrm{db} / \mathrm{db}$ mice and the untreated diabetic $\mathrm{db} / \mathrm{db}$ involved in glucose and FFA metabolism. Fewer genes were regulated by RSG treatment in muscle in comparison to the liver and IAT. However, similarly to the differential gene expression observed between the $\mathrm{db} /+$ and $\mathrm{db} / \mathrm{db}$ diabetic mice, RSG induced an upregulation of key genes involved in carbohydrate metabolism such as $\mathrm{Pkm} 2(+44 \%,+45 \%$, and $+42 \%$ at 10,30 , and $100 \mathrm{mg} / \mathrm{kg}$ RSG, resp.) and HK1 (+57\%, $+60 \%$, and $+69 \%)$. Moreover, RSG treatment resulted in the repression of genes involved in lipid transport (Figure 6(a)), like Cd36 (42\%, 30\%, and $11 \%$ at 10, 30, and $100 \mathrm{mg} / \mathrm{kg} \mathrm{RSG}$, resp.) and Fabp 4 (59\%, 35\%, and +30\%). RSG also decreased the expression of genes involved in FA and TG metabolism like Acaca $(25 \%, 40 \%$, and $16 \%$ at 10,30 , and $100 \mathrm{mg} / \mathrm{kg}$ RSG, resp.) and MgII (32\%, 14\%, and +33\%) (Figure 6(a)). It is noteworthy that the changes induced in gene expression by $10 \mathrm{mg} / \mathrm{kg}$ RSG tended to be most similar to $\mathrm{db} /+$ versus $\mathrm{db} / \mathrm{db}$ than the 30 and $100 \mathrm{mg} / \mathrm{kg}$ doses (see Figure 6(a), Acaca, Fabp4 or Mgll). This tendency seemed to be specific to soleus muscle and suggests possible toxic or secondary effects of high RSG concentrations. Taken together, these results suggest a decrease in FFA uptake and an increase in glucose utilization in soleus muscle of RSG-treated animals.

3.9. PLS Analysis. Multivariate statistical approach (PLS) has been applied in order to establish potential relationships between the changes in transcriptional profile and metabolic parameters under RSG treatments (Table 1). This method utilizes a linear regression model on latent structure to find correlations between two data matrices
(X and $\mathrm{Y}$ ). The significant differentially expressed sequences (Supplemental Table 2) involved in metabolism were defined as predictor variables (X) and FFA, TG (tissues and plasma) and glucose concentrations were defined as observation variables (Y). The models were retained based on $R^{2}$ Ycum (\% of explained sum of squares), $Q^{2}{ }_{\text {Ycum }}$ ( $\%$ of predictive sum of squares) and $P$-value. No model based on differential gene expression using data from IAT (391 sequences) and soleus (186 sequences) could be obtained. However, the predictor variables corresponding to differentially expressed sequences in liver (276) enable us to derive significant PLS models regarding the $\mathrm{Y}$ variables such as oleic acid and trioleate tissue concentrations (Table 2) as well as the liver weight. Figures 7(a), 7(b) show the correlation between the observed trioleate concentrations or liver weight and the predicted ones obtained from PLS models built using the 40 best sequence predictors $\left(R^{2}\right.$ ycum $=0.89$ and 0.96 , resp. $)$. Among the 40 sequence predictors for liver trioleate concentrations and weight, 20 are common. Removing redundancy among the 20 predictors led to 16 genes from which 13 displayed PPRE in their proximal promoters as determined by MatInspector from Genomatix suite (see Section 2 and Supplemental Table 4). An interesting observation is that using the combination of differential gene expression from the three tissues ( 853 gene sequences) we were able to find a PLS model that made the link between predictor gene sequences and the blood glucose concentrations. Correlation between observed and predicted glucose using the 40 best predictors led to an acceptable model $(P=.007$ and $R_{\text {Ycum }}^{2}=0.83$; Figure $\left.7(\mathrm{c})\right)$ but predictive potency of the model remained rather weak $\left(Q_{Y c u m}^{2}=0.68\right)$. Among the 40 predictors 35 belong to the IAT, 4 to the liver, and 1 to the soleus. A great deal of IAT mRNA- $(24 / 35$ sequences) encoded proteins involved in the mitochondrial 
TABLE 3: Differential expression of the 40 best predictor gene sequences from PLS analysis of combined tissues: liver, IAT, and soleus. x: MatInspector-predicted PPRE.

\begin{tabular}{|c|c|c|c|c|c|c|c|c|}
\hline Tissues & $\begin{array}{l}\text { Gene } \\
\text { name }\end{array}$ & Function & $\begin{array}{l}\text { Sequence } \\
\text { description }\end{array}$ & PPRE & $\mathrm{db} /+$ & RSG $10 \mathrm{MK}$ & RSG $30 \mathrm{MK}$ & RSG $100 \mathrm{MK}$ \\
\hline & & & & & F. C. & F. C. & F. C. & F. C. \\
\hline S & Сур4a12a & $\begin{array}{l}\text { Fatty acid } \\
\text { metabolism }\end{array}$ & $\begin{array}{l}\text { cytochrome } \mathrm{P} 450 \text {, } \\
\text { family } 4 \text {, subfamily } \\
\text { a, polypeptide } 12 \mathrm{a}\end{array}$ & & 1.72 & 1.25 & 1.27 & 1.46 \\
\hline TA & Dci & $\begin{array}{l}\text { Fatty acid } \\
\text { metabolism }\end{array}$ & $\begin{array}{l}\text { dodecenoyl- } \\
\text { Coenzyme A delta } \\
\text { isomerase ( } 3,2 \\
\text { trans-enoyl- } \\
\text { Coenzyme A } \\
\text { isomerase) }\end{array}$ & $\mathrm{x}$ & 1.51 & 1.28 & 1.68 & 1.85 \\
\hline TA & Mcat & $\begin{array}{l}\text { Fatty acid } \\
\text { metabolism }\end{array}$ & $\begin{array}{l}\text { malonyl CoA: ACP } \\
\text { acyltransferase } \\
\text { (mitochondrial) }\end{array}$ & & 1.57 & 1.29 & 1.54 & 1.66 \\
\hline TA & Ppargclb & $\begin{array}{l}\text { Fatty acid } \\
\text { metabolism }\end{array}$ & $\begin{array}{l}\text { peroxisome } \\
\text { proliferative } \\
\text { activated receptor, } \\
\text { gamma, } \\
\text { coactivator } 1 \text { beta }\end{array}$ & & 1.63 & -1.06 & 1.37 & 1.83 \\
\hline TA & Ppargclb & $\begin{array}{l}\text { Fatty acid } \\
\text { metabolism }\end{array}$ & $\begin{array}{l}\text { peroxisome } \\
\text { proliferative } \\
\text { activated receptor, } \\
\text { gamma, } \\
\text { coactivator } 1 \text { beta }\end{array}$ & & 2.11 & 1.10 & 1.67 & 2.33 \\
\hline TA & Ppargclb & $\begin{array}{l}\text { Fatty acid } \\
\text { metabolism }\end{array}$ & $\begin{array}{l}\text { peroxisome } \\
\text { proliferative } \\
\text { activated receptor, } \\
\text { gamma, } \\
\text { coactivator } 1 \text { beta }\end{array}$ & & 1.41 & -1.10 & 1.30 & 1.80 \\
\hline $\mathrm{TA}$ & Dlat & Gluconeogenesis & $\begin{array}{l}\text { dihydrolipoamide } \\
\text { S-acetyltransferase } \\
\text { (E2 component of } \\
\text { pyruvate } \\
\text { dehydrogenase } \\
\text { complex) }\end{array}$ & $\mathrm{x}$ & 1.77 & 1.49 & 2.10 & 2.72 \\
\hline TA & Ldhb & Gluconeogenesis & $\begin{array}{l}\text { lactate } \\
\text { dehydrogenase B }\end{array}$ & & 1.76 & 1.07 & 1.36 & 1.81 \\
\hline TA & Pdhb & Gluconeogenesis & $\begin{array}{l}\text { pyruvate } \\
\text { dehydrogenase } \\
\text { (lipoamide) beta }\end{array}$ & & 2.19 & 1.69 & 2.49 & 3.05 \\
\hline TA & Pdhb & Gluconeogenesis & $\begin{array}{l}\text { pyruvate } \\
\text { dehydrogenase } \\
\text { (lipoamide) beta }\end{array}$ & & 2.04 & 1.65 & 2.32 & 2.82 \\
\hline $\mathrm{L}$ & Pfkfb2 & Gluconeogenesis & $\begin{array}{l}\text { 6-phosphofructo- } \\
\text { 2-kinase/fructose- } \\
\text { 2,6-biphosphatase } \\
2\end{array}$ & $\mathrm{x}$ & -1.16 & -1.72 & -1.59 & -1.56 \\
\hline $\mathrm{L}$ & Ppargcla & Gluconeogenesis & $\begin{array}{l}\text { peroxisome } \\
\text { proliferative } \\
\text { activated receptor, } \\
\text { gamma, } \\
\text { coactivator } 1 \text { alpha }\end{array}$ & $\mathrm{x}$ & -1.32 & -1.53 & -1.61 & -1.59 \\
\hline $\mathrm{L}$ & Ppargcla & Gluconeogenesis & $\begin{array}{l}\text { peroxisome } \\
\text { proliferative } \\
\text { activated receptor, } \\
\text { gamma, } \\
\text { coactivator } 1 \text { alpha }\end{array}$ & & -1.64 & -1.71 & -1.75 & -1.75 \\
\hline
\end{tabular}


Table 3: Continued.

\begin{tabular}{|c|c|c|c|c|c|c|c|c|}
\hline Tissues & $\begin{array}{l}\text { Gene } \\
\text { name }\end{array}$ & Function & $\begin{array}{l}\text { Sequence } \\
\text { description }\end{array}$ & PPRE & $\mathrm{db} /+$ & RSG $10 \mathrm{MK}$ & RSG $30 \mathrm{MK}$ & RSG $100 \mathrm{MK}$ \\
\hline TA & Atp5h & $\begin{array}{l}\text { Mitochondrial } \\
\text { respiratory } \\
\text { chain }\end{array}$ & $\begin{array}{l}\text { ATP synthase, H+ } \\
\text { transporting, } \\
\text { mitochondrial F0 } \\
\text { complex, subunit d }\end{array}$ & $\mathrm{x}$ & 1.21 & 1.07 & 1.26 & 1.41 \\
\hline TA & Atp5h & $\begin{array}{l}\text { Mitochondrial } \\
\text { respiratory } \\
\text { chain }\end{array}$ & $\begin{array}{l}\text { ATP synthase, H+ } \\
\text { transporting, } \\
\text { mitochondrial F0 } \\
\text { complex, subunit d }\end{array}$ & & 1.23 & 1.06 & 1.26 & 1.47 \\
\hline TA & Cox6b1 & $\begin{array}{l}\text { Mitochondrial } \\
\text { respiratory } \\
\text { chain }\end{array}$ & $\begin{array}{l}\text { cytochrome c } \\
\text { oxidase, subunit } \\
\text { VIb polypeptide } 1\end{array}$ & & 1.54 & 1.39 & 1.82 & 2.16 \\
\hline TA & Cox6b2 & $\begin{array}{l}\text { Mitochondrial } \\
\text { respiratory } \\
\text { chain }\end{array}$ & $\begin{array}{l}\text { cytochrome c } \\
\text { oxidase, subunit } \\
\text { VIb polypeptide } 2\end{array}$ & & 1.35 & 1.08 & 1.37 & 1.59 \\
\hline TA & Cox7a1 & $\begin{array}{l}\text { Mitochondrial } \\
\text { respiratory } \\
\text { chain }\end{array}$ & $\begin{array}{l}\text { cytochrome c } \\
\text { oxidase, subunit } \\
\text { VIIa } 1\end{array}$ & $\mathrm{x}$ & 1.37 & -1.52 & 1.45 & 1.98 \\
\hline TA & Cox7b & $\begin{array}{l}\text { Mitochondrial } \\
\text { respiratory } \\
\text { chain }\end{array}$ & $\begin{array}{l}\text { cytochrome c } \\
\text { oxidase, subunit } \\
\text { VIIb }\end{array}$ & $\mathrm{x}$ & 1.96 & 1.33 & 1.87 & 2.15 \\
\hline TA & Ndufa1 & $\begin{array}{l}\text { Mitochondrial } \\
\text { respiratory } \\
\text { chain }\end{array}$ & $\begin{array}{l}\text { NADH } \\
\text { dehydrogenase } \\
\text { (ubiquinone) } 1 \\
\text { alpha subcomplex, } \\
1\end{array}$ & $\mathrm{x}$ & 1.44 & 1.13 & 1.42 & 1.52 \\
\hline TA & Ndufal & $\begin{array}{l}\text { Mitochondrial } \\
\text { respiratory } \\
\text { chain }\end{array}$ & $\begin{array}{l}\text { NADH } \\
\text { dehydrogenase } \\
\text { (ubiquinone) } 1 \\
\text { alpha subcomplex, } \\
1\end{array}$ & & 1.35 & 1.09 & 1.31 & 1.46 \\
\hline TA & Uqcrb & $\begin{array}{l}\text { Mitochondrial } \\
\text { respiratory } \\
\text { chain }\end{array}$ & $\begin{array}{l}\text { ubiquinol- } \\
\text { cytochrome c } \\
\text { reductase binding } \\
\text { protein }\end{array}$ & $\mathrm{x}$ & 1.81 & 1.40 & 1.82 & 2.14 \\
\hline TA & Uqcrfs1 & $\begin{array}{l}\text { Mitochondrial } \\
\text { respiratory } \\
\text { chain }\end{array}$ & $\begin{array}{l}\text { ubiquinol- } \\
\text { cytochrome c } \\
\text { reductase, Rieske } \\
\text { iron-sulfur } \\
\text { polypeptide } 1\end{array}$ & & 1.57 & 1.24 & 1.87 & 2.25 \\
\hline TA & Uqcrh & $\begin{array}{l}\text { Mitochondrial } \\
\text { respiratory } \\
\text { chain }\end{array}$ & $\begin{array}{l}\text { ubiquinol- } \\
\text { cytochrome c } \\
\text { reductase hinge } \\
\text { protein }\end{array}$ & & 1.89 & 1.43 & 1.81 & 1.97 \\
\hline TA & Uqcrh & $\begin{array}{l}\text { Mitochondrial } \\
\text { respiratory } \\
\text { chain }\end{array}$ & $\begin{array}{l}\text { ubiquinol- } \\
\text { cytochrome c } \\
\text { reductase hinge } \\
\text { protein }\end{array}$ & & 1.65 & 1.28 & 1.57 & 1.83 \\
\hline TA & Fntb & $\begin{array}{l}\text { Steroid } \\
\text { biosynthesis }\end{array}$ & $\begin{array}{l}\text { farnesyltransferase, } \\
\text { CAAX box, beta }\end{array}$ & $\mathrm{x}$ & 1.48 & 1.43 & 1.55 & 1.49 \\
\hline $\mathrm{L}$ & Hmgcs2 & $\begin{array}{l}\text { Steroid } \\
\text { biosynthesis }\end{array}$ & $\begin{array}{l}\text { 3-hydroxy-3- } \\
\text { methylglutaryl- } \\
\text { Coenzyme A } \\
\text { synthase } 2\end{array}$ & $\mathrm{x}$ & -1.32 & -1.09 & -1.28 & -1.37 \\
\hline TA & Agpat3 & Triglyceride & $\begin{array}{l}\text { 1-acylglycerol-3- } \\
\text { phosphate } \\
\text { O-acyltransferase } 3\end{array}$ & $\mathrm{x}$ & 1.81 & 1.31 & 1.65 & 2.07 \\
\hline
\end{tabular}


Table 3: Continued.

\begin{tabular}{|c|c|c|c|c|c|c|c|c|}
\hline Tissues & $\begin{array}{l}\text { Gene } \\
\text { name }\end{array}$ & Function & $\begin{array}{l}\text { Sequence } \\
\text { description }\end{array}$ & PPRE & $\mathrm{db} /+$ & RSG $10 \mathrm{MK}$ & RSG $30 \mathrm{MK}$ & RSG $100 \mathrm{MK}$ \\
\hline TA & Acol & $\begin{array}{l}\text { Tricarboxylic } \\
\text { acid cycle (mit } \\
\text { oxidation) }\end{array}$ & aconitase 1 & $\mathrm{x}$ & 1.77 & 1.37 & 1.70 & 1.94 \\
\hline TA & Aco 2 & $\begin{array}{l}\text { Tricarboxylic } \\
\text { acid cycle (mit } \\
\text { oxidation) }\end{array}$ & $\begin{array}{l}\text { aconitase 2, } \\
\text { mitochondrial }\end{array}$ & $\mathrm{x}$ & 1.38 & 1.18 & 1.66 & 1.98 \\
\hline TA & Aldh5a1 & $\begin{array}{l}\text { Tricarboxylic } \\
\text { acid cycle (mit } \\
\text { oxidation) }\end{array}$ & $\begin{array}{l}\text { aldhehyde } \\
\text { dehydrogenase } \\
\text { family } 5 \text {, subfamily } \\
\text { A1 }\end{array}$ & $\mathrm{x}$ & 1.60 & 1.33 & 1.65 & 1.69 \\
\hline TA & Dlst & $\begin{array}{l}\text { Tricarboxylic } \\
\text { acid cycle (mit } \\
\text { oxidation) }\end{array}$ & $\begin{array}{l}\text { dihydrolipoamide } \\
\text { S- } \\
\text { succinyltransferase } \\
\text { (E2 component of } \\
\text { 2-oxo-glutarate } \\
\text { complex) }\end{array}$ & $\mathrm{x}$ & 1.43 & 1.16 & 1.63 & 1.83 \\
\hline TA & Fh1 & $\begin{array}{l}\text { Tricarboxylic } \\
\text { acid cycle (mit } \\
\text { oxidation) }\end{array}$ & $\begin{array}{l}\text { fumarate hydratase } \\
1\end{array}$ & $\mathrm{x}$ & 1.56 & 1.28 & 1.63 & 1.87 \\
\hline TA & Idh3b & $\begin{array}{l}\text { Tricarboxylic } \\
\text { acid cycle (mit } \\
\text { oxidation) }\end{array}$ & $\begin{array}{l}\text { isocitrate } \\
\text { dehydrogenase } 3 \\
(\mathrm{NAD}+) \text {, beta }\end{array}$ & $\mathrm{x}$ & 1.49 & 1.18 & 1.73 & 1.91 \\
\hline TA & Idh3g & $\begin{array}{l}\text { Tricarboxylic } \\
\text { acid cycle (mit } \\
\text { oxidation) }\end{array}$ & $\begin{array}{l}\text { isocitrate } \\
\text { dehydrogenase } 3 \\
(\mathrm{NAD}+) \text {, gamma }\end{array}$ & $\mathrm{x}$ & 1.67 & 1.18 & 1.59 & 1.91 \\
\hline TA & Mdh1 & $\begin{array}{l}\text { Tricarboxylic } \\
\text { acid cycle (mit } \\
\text { oxidation) }\end{array}$ & $\begin{array}{l}\text { malate } \\
\text { dehydrogenase 1, } \\
\text { NAD (soluble) }\end{array}$ & & 1.93 & 1.17 & 1.91 & 1.95 \\
\hline TA & Mdh1 & $\begin{array}{l}\text { Tricarboxylic } \\
\text { acid cycle (mit } \\
\text { oxidation) }\end{array}$ & $\begin{array}{l}\text { malate } \\
\text { dehydrogenase 1, } \\
\text { NAD (soluble) }\end{array}$ & & 1.63 & 1.44 & 2.01 & 2.17 \\
\hline TA & Sdhb & $\begin{array}{l}\text { Tricarboxylic } \\
\text { acid cycle (mit } \\
\text { oxidation) }\end{array}$ & $\begin{array}{l}\text { succinate } \\
\text { dehydrogenase } \\
\text { complex, subunit } \\
\text { B, iron sulfur (Ip) }\end{array}$ & & 1.60 & 1.21 & 1.67 & 1.97 \\
\hline TA & Sdhc & $\begin{array}{l}\text { Tricarboxylic } \\
\text { acid cycle (mit } \\
\text { oxidation) }\end{array}$ & $\begin{array}{l}\text { succinate } \\
\text { dehydrogenase } \\
\text { complex, subunit } \\
\text { C, integral } \\
\text { membrane protein }\end{array}$ & $\mathrm{x}$ & 1.32 & 1.10 & 1.35 & 1.48 \\
\hline TA & Sdhd & $\begin{array}{l}\text { Tricarboxylic } \\
\text { acid cycle (mit } \\
\text { oxidation) }\end{array}$ & $\begin{array}{l}\text { succinate } \\
\text { dehydrogenase } \\
\text { complex, subunit } \\
\text { D, integral } \\
\text { membrane protein }\end{array}$ & $\mathrm{x}$ & 1.29 & 1.11 & 1.57 & 1.90 \\
\hline
\end{tabular}

respiration and tricarboxylic acid cycle (Table 3 ) and 3 out of 4 genes from liver are involved in gluconeogenesis. Finally, among the 32 unique genes (corresponding to the 40 gene sequences), 21 presented a PPRE in their promoter regulatory sequences.

These observations underline the link between RSGmediated PPAR $\gamma$ activation and expression of genes involved in IAT mitochondrial function, liver gluconeogenesis, and regulation of blood glucose.

\section{Discussion}

In this paper, for the first time we have attempted to establish a link between metabolic status of RSG-treated diabetic mice $(\mathrm{db} / \mathrm{db})$ and RSG-mediated transcriptomic changes in the three major insulin-dependent tissues including liver, adipose tissue, and skeletal muscle.

As expected, numerous genes regulated by RSG and identified in this study fall into key metabolic pathways involved in carbohydrate and lipid metabolism. PPAR $y$ 


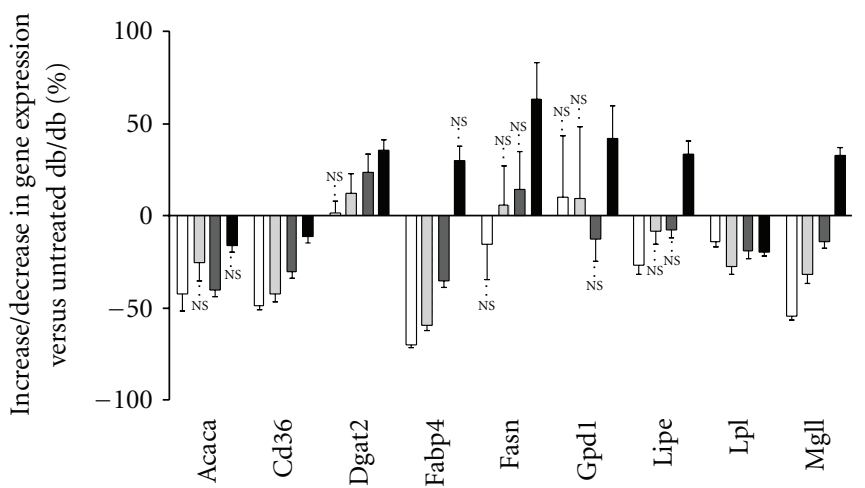

(a)



(b)

Figure 6: Expression profiles of key genes involved in Soleus muscle glucose and lipid metabolism. Differentially expressed genes in db/+ (the white square) and 10 (the off-white square), 30 (the grey square), and 100 (the black square) $\mathrm{mg} / \mathrm{kg}$ RSG-treated $\mathrm{db} / \mathrm{db}$ mice were measured versus untreated $\mathrm{db} / \mathrm{db}$ and plotted as the mean (\% increase/decrease of $\mathrm{db} / \mathrm{db}$ control) \pm SEM $(n=6)$. NS; $P \geq .001$ otherwise $P<.001$. (a) Genes related to glucose metabolism*: Eno3, enolase 3, beta muscle; Hk1, hexokinase 1; Pkm2, pyruvate kinase, muscle; Pgm2, phosphoglucomutase 2; Pygm, muscle glycogen phosphorylase. (b) Genes related to lipid metabolism: Dgat2, diacylglycerol Oacyltransferase 2; Lipe, lipase hormone sensitive; * gene abbreviations given in Figures 1, and 4 were not mentioned.

agonist also regulates many more genes in adipose tissue than in liver or skeletal muscle, as might be expected, based on PPAR $y$ expression levels in the respective tissues. Despite this difference, our data showed that PPAR $\gamma$ activation has coordinated effects on fundamental metabolic pathways in each of these tissues, including glucose and lipid metabolism in skeletal muscle, gluconeogenesis in liver, as well as lipogenesis, TG storage, and mitochondrial function in adipose tissue. Gene transcription modulation by RSG could be classified into two types, namely, those which counteract diabetes-induced alteration and correlated to the modulation observed in $\mathrm{db} /+$ versus $\mathrm{db} / \mathrm{db}$ and those which accentuate diabetes induced alteration and are inversely correlated. The first group could explain the glucose and lipid-lowering actions of PPAR $\gamma$ agonists, and the second group could be linked to TZDs compound-mediated side effects.

4.1. Liver. One of the most interesting observations is that RSG treatment normalised glucose homeostasis in $\mathrm{db} / \mathrm{db}$ mice (result presented here in and in [15]) and the mRNA expression of gluconeogenic key enzymes such as the G6pc, Fbp1, and the glucose transporter Glut-2. These results suggest that transcriptional regulation of G6pc and Fbp1 mRNA play a role in RSG-mediated decreased gluconeogenesis and blood glucose normalisation. This observation is in agreement with previous studies showing an increase in G6pc and Fbp1 activities in $\mathrm{db} / \mathrm{db}$ mice and the subsequent increase in glucose production by the $\mathrm{db} / \mathrm{db}$ liver [25].

In human, hepatic gluconeogenesis is known to be significantly enhanced in type 2 diabetes and normalised by $\operatorname{RSG}[10,26]$. Therefore, the transcriptional status of G6Pc and Fbp1, related to RSG-mediated gluconeogenesis normalisation, deserves to be further investigated in humans.

In rodents one of the thiazolidinedione treatment side effects is associated with liver dysfunction. RSG-treated $\mathrm{db} / \mathrm{db}$ mice have shown a rise in their liver weight and steatosis appearance, as previously shown [12]. Indeed, the potent antihyperglycaemic effect of RSG was accompanied by an increase of de novo synthesis of fatty acids when compared to either $\mathrm{db} /+$ or $\mathrm{db} / \mathrm{db}$. Lipid metabolome analysis was concordant with our gene expression profiling obtained in liver and corroborate with the results obtained in a previous study [13]. A rise in hepatic expression of genes belonging to numerous steps of the TG synthesis in liver was observed under RSG treatment including those that encode for FA transporters (Lpl, Cd36, Fabp2, 4), TG (Gpd1) and FFA synthesis (Acly, Fasn, Acaca, Gpd1, Agpat2, 6, Scd1) and are likely associated to the RSGmediated increase in hepatic trioleate levels. This result is in contrast with the RSG effects in humans and normal mice, where chronic RSG treatment reduced liver fat [27, 28]. However $\mathrm{db} / \mathrm{db}$ is a leptin signalling deficient paradigm, and numerous publications demonstrated in wild-type mice that leptin decreases hepatic de novo synthesis of FA through the decrease in mRNA, proteins, or enzymatic activities of FFA and TG metabolism enzymes including Acly, Acaca, Fas, Scd1, or Agpat [29-33]. Therefore, mice lacking leptin signalling are not the best paradigm to foresee PPAR agonist secondary effects in human liver.

4.2. Inguinal Adipose Tissue. In adipose tissue, mitochondria are not only the major site of fatty acid oxidation but may also play a critical role in lipogenesis by providing key intermediates for TG synthesis. Impaired mitochondria may lead to the lack of ATP and subsequent reduction in lipid metabolism [23]. This dysfunction could be linked to a reduced ability of glucose utilization, participating in high blood glucose levels in diabetic mice. A decrease in ATP may also impair the synthesis and secretion of adipokines, which were previously shown to be associated with diabetes [34]. In our study, RSG significantly induced a dose-dependent increase in a number of genes implicated in 


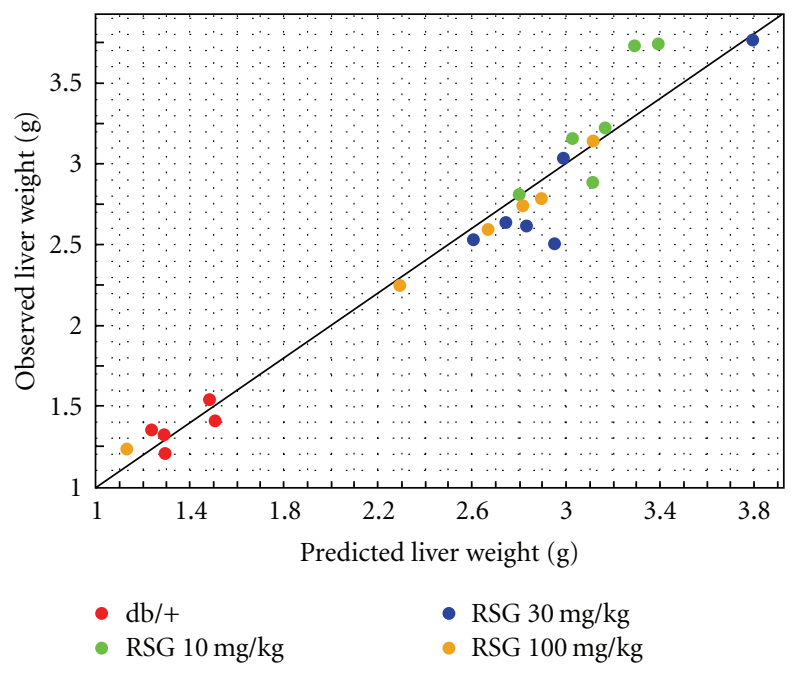

(a)

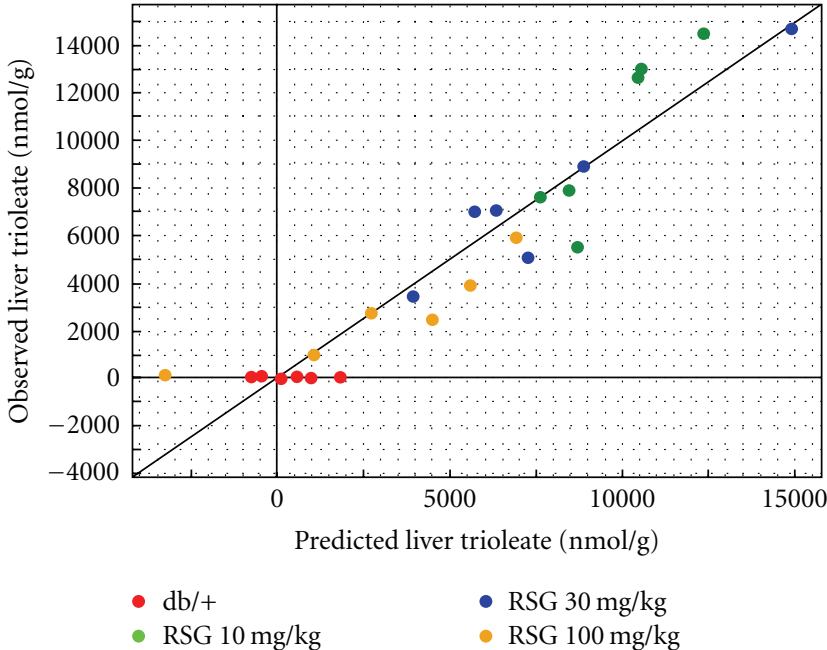

(b)

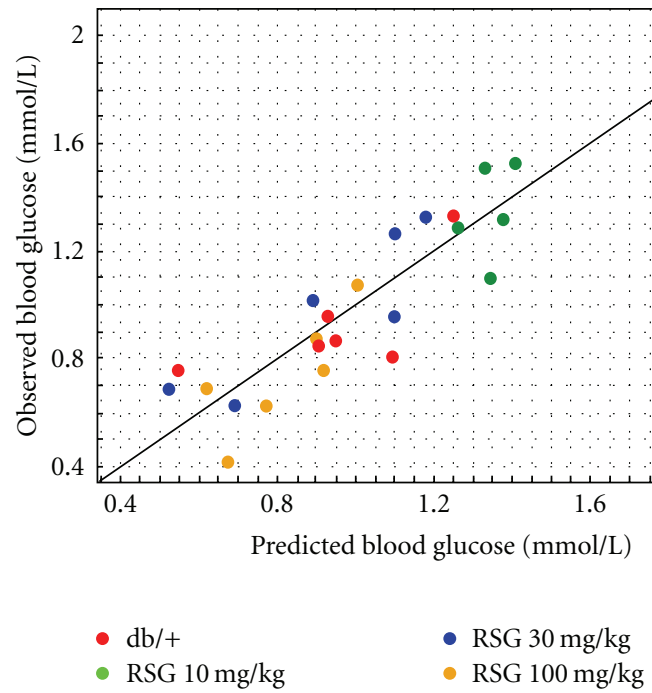

(c)

FIGURE 7: Generation of PLS models to predict physiological changes from multivariate gene expression data. Results show the correlations between the actual liver weight (a), the liver trioleate concentrations (b), the blood glucose level (c) and the predicted parameters from the PLS model. The normalised logs (ratio) of genes involved in glucose and lipid metabolism were used as predictor variables (X) and physiological parameters as response variables $(\mathrm{Y})$. All variables were centred and scaled to unit variance, before the PLS analysis was performed.

mitochondrial activities. Genes encoding for enzymes involved in $\beta$-oxidation, citrate cycle, and oxidative phosphorylation were upregulated in a similar manner to that observed in $\mathrm{db} /+$ versus $\mathrm{db} / \mathrm{db}$ mice. Moreover, we have observed an upregulation of PPAR $\gamma$ coactivator PGC1 $\alpha$ (data not shown), which is known to potently activate mitochondrial biogenesis in adipose and muscle tissues $[24,35]$. Combined with immunocytochemistry results, these data showed that RSG treatment led to an increase in mitochondrial biogenesis. The effects of PPAR $y$ agonist on both mitochondrial number and morphology were previously observed in adipose tissues of rat and dog treated with RSG [36]. RSG is also known to induce adipocyte differentiation and mitochondrial biogenesis [37]. These new small adipocytes are insulin sensitive and possess a higher lipid metabolism capacity that could explain the RSG-increased mRNA of genes involved in lipid transport and oxidation. The IAT is composed of both brown adipose tissue (BAT) and white adipose tissue (WAT). Our data show the upregulation of BAT markers Ucp1 or Cpt1b in IAT of treated mice, as described by others [34]. This observation supports the view of RSG converting WAT to BAT, transforming IAT into fat-oxidizing machinery. They also suggest that decreasing the exposure of peripheral tissues to lipids may improve the whole-body insulin sensitivity.

4.3. Soleus Muscle. Normalisation of hyperglycaemia by RSG-decreased hepatic glucose synthesis and output seems to be combined with better use of glucose in soleus muscle. 
Indeed, RSG-treated mice showed an increased expression of genes coding for key enzymes involved in glycolysis, like Hexokinase1 Hk1, Enolase Eno3, or Pyruvate kinase $\mathrm{Pkm} 2$, similar to our observation in $\mathrm{db} /+$ versus $\mathrm{db} / \mathrm{db}$. RSG treatment of $\mathrm{db} / \mathrm{db}$ also resulted in a coordinated decrease in the expression of some genes involved in fatty acid transport and metabolism in muscle. It is noteworthy that the expression of these genes was upregulated in liver and to a lesser extent in IAT in response to RSG, suggesting that PPAR $\gamma$ activation promotes a flux of fatty acids into hepatic and adipose tissues and away from muscle. Altogether, these data suggest a decreased reliance on fatty acids and an increased reliance on glucose as an energy source in muscle, as previously described $[2,38]$. Surprisingly, the RSG-mediated gene expression normalisation in muscular cells was observed mainly at $10 \mathrm{mg} / \mathrm{kg}$ dose, whereas the highest doses induced the expression of genes related to glucose and lipid pathways in opposite direction to that measured in $\mathrm{db} /+$ versus $\mathrm{db} / \mathrm{db}$, suggesting a possible adverse effect at higher drug concentrations in this tissue.

4.4. PLS Models. Taking advantage of the experimental design including both transcriptomic and metabolomic approaches, we applied a multivariate linear regression model (PLS) in order to predict the metabolic parameters (i.e., blood glucose and FFA and TG from blood and tissues) based on regulated genes (predictor (X) variables). Only the variables $\mathrm{X}$ from liver allowed us to derive models that significantly predicted some of the measured biological parameters such as liver oleic acid and trioleate as well as the liver weight. It is worth noticing that among the 40 best predictors 20 (16 genes) are common between trioleate and the liver weight model. The fact that among these 16 genes 13 display a PPRE and therefore are supposed to be regulated by PPAR agonist reinforces the predictory status of these 20 gene sequences. Obviously more experiments should be undertaken with different RSG dose treatments to confirm these predictors. Moreover, no significant model could be built with differential gene expression data from liver and blood metabolic parameters, and no model could be obtained with IAT or soleus muscle regarding both tissue and blood metabolic parameters. However, the most interesting observation is that a model was validated with blood glucose levels and the combination of gene expression data from the 3 tissues. When looking at the 40 best predictors, we found that a large majority of gene sequences implied IATexpressed genes (35/40), and among the 35, 25 encoded mitochondrial proteins involved in energy cell production and 4 gene sequences were originated from the liver and are involved in gluconeogenesis. In that case we may hypothesise that those blood glucose predictors are linked to molecular mechanisms because; (i) mitochondrial dysfunction is linked to diabetes type 2 and thiazolidinediones were known to improve the diabetes status by the production of more functional adipocytes; (ii) in $\mathrm{db} / \mathrm{db}$ mice high levels of blood glucose partially is due to gluconeogenesis [25] and RSG by decreasing mRNA encoding gluconeogenic enzymes may indeed regulate blood glucose.
Therefore, PLS reveals not only IAT/liver predictors for blood glucose regulation but also a potential molecular mechanism that could explain in part the glucose regulation. Whether or not this mechanism is due to direct PPAR $\gamma$ induced transcriptional effects or PPAR interaction with the mitochondrial protein such as MitoNEET [39] that subsequently activate mitochondrial functions remains to be investigated, but a majority of genes in the top 40 predictor sequences (21/32 genes) displayed predicted PPRE in their respective promoter.

\section{Conclusion}

To our knowledge, this is the first study comparing gene expression profiles between $\mathrm{db} /+$ and RSG-treated $\mathrm{db} / \mathrm{db}$ with control diabetic $\mathrm{db} / \mathrm{db}$ in liver, muscle, and adipose tissues. The combination of transcriptomic and metabolomic approaches led to a comprehensive molecular portrait and hypothesis on the dose-dependent effects of RSG in $\mathrm{db} / \mathrm{db}$ diabetic mice and highlights the role of the respective insulindependent tissues. This approach could be useful in the future to discriminate between selective PPAR modulators regarding their specific molecular profiles in relation to specific target tissues.

\section{Abbreviations}

$\begin{array}{ll}\text { FFAs: } & \text { Free fatty acids } \\ \text { RSG: } & \text { Rosiglitazone } \\ \text { IAT: } & \text { Inguinal adipose tissue } \\ \text { PPAR: } & \text { Peroxisome proliferator-activated receptor } \\ \text { PPRE: } & \text { PPAR response element } \\ \text { PLSs: } & \text { Partial least squares } \\ \text { TZD: } & \text { Thiazolidinedione } \\ \text { TGs: } & \text { Triglycerides } \\ \text { UPLC-MS: } & \text { Ultra performance liquid } \\ & \text { chromatography-mass spectrometry. }\end{array}$

\section{Acknowledgment}

The authors wish to thank C. Bourrier, I. Naime, and J. Richard (Institut de Recherche Servier, Croissy-sur-Seine, France) for expert technical assistance.

\section{References}

[1] G. Jiang, Q. Dallas-Yang, Z. Li et al., "Potentiation of insulin signaling in tissues of Zucker obese rats after acute and longterm treatment with PPAR $\gamma$ agonists," Diabetes, vol. 51 , no. 8 , pp. 2412-2419, 2002.

[2] A. B. Mayerson, R. S. Hundal, S. Dufour et al., "The effects of rosiglitazone on insulin sensitivity, lipolysis, and hepatic and skeletal muscle triglyceride content in patients with type 2 diabetes," Diabetes, vol. 51, no. 3, pp. 797-802, 2002.

[3] A. M. Sharma and B. Staels, "Review: peroxisome proliferatoractivated receptor $\gamma$ and adipose tissue-understanding obesity-related changes in regulation of lipid and glucose metabolism," Journal of Clinical Endocrinology and Metabolism, vol. 92, no. 2, pp. 386-395, 2007. 
[4] C. Tiraby, G. Tavernier, C. Lefort et al., "Acquirement of brown fat cell features by human white adipocytes," Journal of Biological Chemistry, vol. 278, no. 35, pp. 33370-33376, 2003.

[5] D. L. Gerhold, F. Liu, G. Jiang et al., "Gene expression profile of adipocyte differentiation and its regulation by peroxisome proliferator-activated receptor- $\gamma$ agonists," Endocrinology, vol. 143, no. 6, pp. 2106-2118, 2002.

[6] L. Teboul, D. Gaillard, L. Staccini, H. Inadera, E.-Z. Amri, and P. A. Grimaldi, "Thiazolidinediones and fatty acids convert myogenic cells into adipose-like cells," Journal of Biological Chemistry, vol. 270, no. 47, pp. 28183-28187, 1995.

[7] P. Tontonoz, E. Hu, R. A. Graves, A. I. Budavari, and B. M. Spiegelman, "mPPAR $\gamma 2$ : tissue-specific regulator of an adipocyte enhancer," Genes and Development, vol. 8, no. 10, pp. 1224-1234, 1994.

[8] S. Hallakou, L. Doaré, F. Foufelle et al., "Pioglitazone induces in vivo adipocyte differentiation in the obese Zucker fa/fa rat," Diabetes, vol. 46, no. 9, pp. 1393-1399, 1997.

[9] Y. Zhu, K. Alvares, Q. Huang, M. S. Rao, and J. K. Reddy, "Cloning of a new member of the peroxisome proliferatoractivated receptor gene family from mouse liver," Journal of Biological Chemistry, vol. 268, no. 36, pp. 26817-26820, 1993.

[10] A. Gastaldelli, Y. Miyazaki, M. Pettiti et al., "The effect of rosiglitazone on the liver: decreased gluconeogenesis in patients with type 2 diabetes," Journal of Clinical Endocrinology and Metabolism, vol. 91, no. 3, pp. 806-812, 2006.

[11] C. J. de Souza, M. Eckhardt, K. Gagen et al., "Effects of pioglitazone on adipose tissue remodeling within the setting of obesity and insulin resistance," Diabetes, vol. 50, no. 8, pp. 1863-1871, 2001.

[12] I. García-Ruiz, C. Rodríguez-Juan, T. Díaz-Sanjuán, M. Á. Martínez, T. Muñoz-Yagüe, and J. A. Solís-Herruzo, "Effects of rosiglitazone on the liver histology and mitochondrial function in ob/ob mice," Hepatology, vol. 46, no. 2, pp. 414423, 2007.

[13] S. M. Watkins, P. R. Reifsnyder, H.-J. Pan, J. B. German, and E. H. Leiter, "Lipid metabolome-wide effects of the PPAR $\gamma$ agonist rosiglitazone," Journal of Lipid Research, vol. 43, no. 11, pp. 1809-1817, 2002.

[14] P. Wang, J. Renes, F. Bouwman, A. Bunschoten, E. Mariman, and J. Keijer, "Absence of an adipogenic effect of rosiglitazone on mature 3T3-L1 adipocytes: increase of lipid catabolism and reduction of adipokine expression," Diabetologia, vol. 50, no. 3, pp. 654-665, 2007.

[15] M. Loffler, M. Bilban, M. Reimers, W. Waldhäusl, and T. M. Stulnig, "Blood glucose-lowering nuclear receptor agonists only partially normalize hepatic gene expression in $\mathrm{db} / \mathrm{db}$ mice," Journal of Pharmacology and Experimental Therapeutics, vol. 316, no. 2, pp. 797-804, 2006.

[16] J. M. Way, W. W. Harrington, K. K. Brown et al., "Comprehensive messenger ribonucleic acid profiling reveals that peroxisome proliferator-activated receptor $\gamma$ activation has coordinate effects on gene expression in multiple insulinsensitive tissues," Endocrinology, vol. 142, no. 3, pp. 12691277, 2001.

[17] A. Suzuki, T. Yasuno, H. Kojo, J. Hirosumi, S. Mutoh, and Y. Notsu, "Alteration in expression profiles of a series of diabetes-related genes in $\mathrm{db} / \mathrm{db}$ mice following treatment with thiazolidinediones," Japanese Journal of Pharmacology, vol. 84, no. 2, pp. 113-123, 2000.

[18] K. Kobayashi, T. M. Forte, S. Taniguchi, B. Y. Ishida, K. Oka, and L. Chan, "The $\mathrm{db} / \mathrm{db}$ mouse, a model for diabetic dyslipidemia: molecular characterization and effects of western diet feeding," Metabolism: Clinical and Experimental, vol. 49, no. 1, pp. 22-31, 2000.

[19] L. Weng, H. Dai, Y. Zhan, Y. He, S. B. Stepaniants, and D. E. Bassett, "Rosetta error model for gene expression analysis," Bioinformatics, vol. 22, no. 9, pp. 1111-1121, 2006.

[20] K. Cartharius, K. Frech, K. Grote et al., "MatInspector and beyond: promoter analysis based on transcription factor binding sites," Bioinformatics, vol. 21, no. 13, pp. 2933-2942, 2005.

[21] S. Wold, M. Sjöström, and L. Eriksson, "PLS-regression: a basic tool of chemometrics," Chemometrics and Intelligent Laboratory Systems, vol. 58, no. 2, pp. 109-130, 2001.

[22] K. J. Livak and T. D. Schmittgen, "Analysis of relative gene expression data using real-time quantitative PCR and the $2^{-\Delta \Delta C_{\mathrm{T}}}$ method," Methods, vol. 25, no. 4, pp. 402-408, 2001.

[23] H.-J. Choo, J.-H. Kim, O.-B. Kwon et al., "Mitochondria are impaired in the adipocytes of type 2 diabetic mice," Diabetologia, vol. 49, no. 4, pp. 784-791, 2006.

[24] J. X. Rong, Y. Qiu, M. K. Hansen et al., "Adipose mitochondrial biogenesis is suppressed in $\mathrm{db} / \mathrm{db}$ and high-fat diet-fed mice and improved by rosiglitazone," Diabetes, vol. 56, no. 7, pp. 1751-1760, 2007.

[25] T. M. Chan, K. M. Young, N. J. Hutson, F. T. Brumley, and J. H. Exton, "Hepatic metabolism of genetically diabetic (db/db) mice. I. Carbohydrate metabolism," American Journal of Physiology, vol. 229, no. 6, pp. 1702-1712, 1975.

[26] G. Boden, X. Chen, and T. P. Stein, "Gluconeogenesis in moderately and severely hyperglycemic patients with type 2 diabetes mellitus," American Journal of Physiology, vol. 280, no. 1, pp. E23-E30, 2001.

[27] B. A. Neuschwander-Tetri, E. M. Brunt, K. R. Wehmeier, C. A. Sponseller, K. Hampton, and B. R. Bacon, "Interim results of a pilot study demonstrating the early effects of the PPAR- $\gamma$ ligand rosiglitazone on insulin sensitivity, aminotransferases, hepatic steatosis and body weight in patients with nonalcoholic steatohepatitis," Journal of Hepatology, vol. 38, no. 4, pp. 434-440, 2003.

[28] W.-N. Cong, R.-Y. Tao, J.-Y. Tian, G.-T. Liu, and F. Ye, “The establishment of a novel non-alcoholic steatohepatitis model accompanied with obesity and insulin resistance in mice," Life Sciences, vol. 82, no. 19-20, pp. 983-990, 2008.

[29] S. M. Cohen, J. G. Werrmann, and M. R. Tota, "13C NMR study of the effects of leptin treatment on kinetics of hepatic intermediary metabolism," Proceedings of the National Academy of Sciences of the United States of America, vol. 95, no. 13, pp. 7385-7390, 1998.

[30] P. Cohen, M. Miyazaki, N. D. Socci et al., "Role for stearoylCoA desaturase-1 in leptin-mediated weight loss," Science, vol. 297, no. 5579, pp. 240-243, 2002.

[31] J. D. Horton, J. L. Goldstein, and M. S. Brown, "SREBPs: activators of the complete program of cholesterol and fatty acid synthesis in the liver," Journal of Clinical Investigation, vol. 109, no. 9, pp. 1125-1131, 2002.

[32] N. Gallardo, E. Bonzón-Kulichenko, T. Fernández-Agulb́ et al., "Tissue-specific effects of central leptin on the expression of genes involved in lipid metabolism in liver and white adipose tissue," Endocrinology, vol. 148, no. 12, pp. 5604-5610, 2007.

[33] L. Jiang, Q. Wang, Y. Yu et al., "Leptin contributes to the adaptive responses of mice to high-fat diet intake through suppressing the lipogenic pathway," PLoS One, vol. 4, no. 9, Article ID e6884, 2009.

[34] M. Guerro-Millo, "Adipose tissue and adipokines: for better or worse," Diabetes and Metabolism, vol. 30, no. 1, pp. 13-19, 2004. 
[35] Z. Wu, P. Puigserver, U. Andersson et al., "Mechanisms controlling mitochondrial biogenesis and respiration through the thermogenic coactivator PGC-1," Cell, vol. 98, no. 1, pp. 115-124, 1999.

[36] C. D. N. Toseland, S. Campbell, I. Francis, P. J. Bugelski, and N. Mehdi, "Comparison of adipose tissue changes following administration of rosiglitazone in the dog and rat," Diabetes, Obesity and Metabolism, vol. 3, no. 3, pp. 163-170, 2001.

[37] M. Adams, C. T. Montague, J. B. Prins et al., "Activators of peroxisome proliferator-activated receptor $\gamma$ have depot- specific effects on human preadipocyte differentiation," Journal of Clinical Investigation, vol. 100, no. 12, pp. 3149-3153, 1997.

[38] Y. Miyazaki, H. He, L. J. Mandarino, and R. A. DeFronzo, "Rosiglitazone improves downstream insulin receptor signaling in type 2 diabetic patients," Diabetes, vol. 52, no. 8, pp. 1943-1950, 2003.

[39] M. L. Paddock, S. E. Wiley, H. L. Axelrod et al., "MitoNEET is a uniquely folded $2 \mathrm{Fe}-2 \mathrm{~S}$ outer mitochondrial membrane protein stabilized by pioglitazone," Proceedings of the National Academy of Sciences of the United States of America, vol. 104, no. 36, pp. 14342-14347, 2007. 




The Scientific World Journal
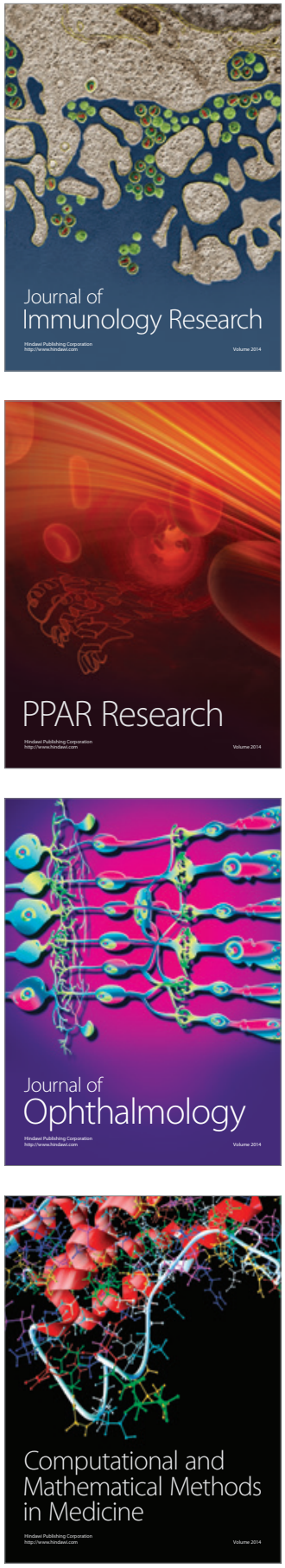

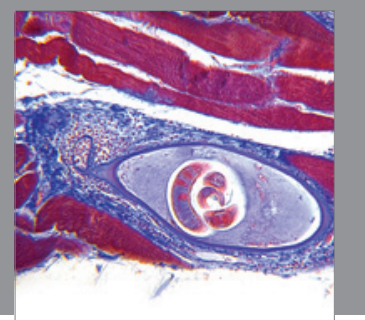

Gastroenterology

Research and Practice
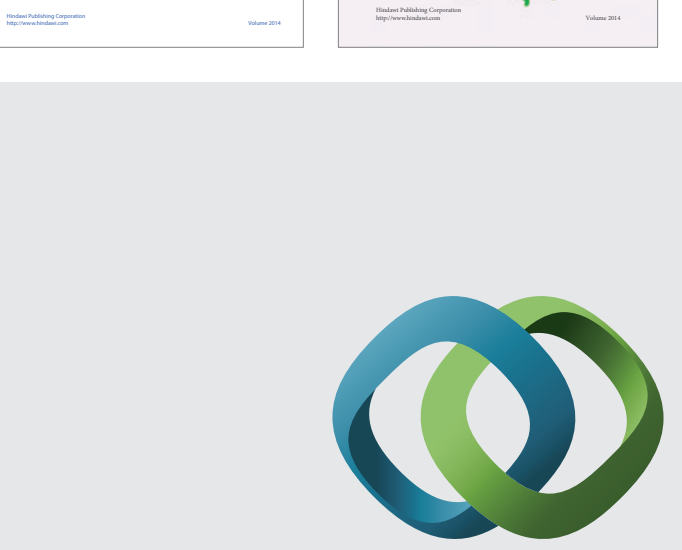

\section{Hindawi}

Submit your manuscripts at

http://www.hindawi.com
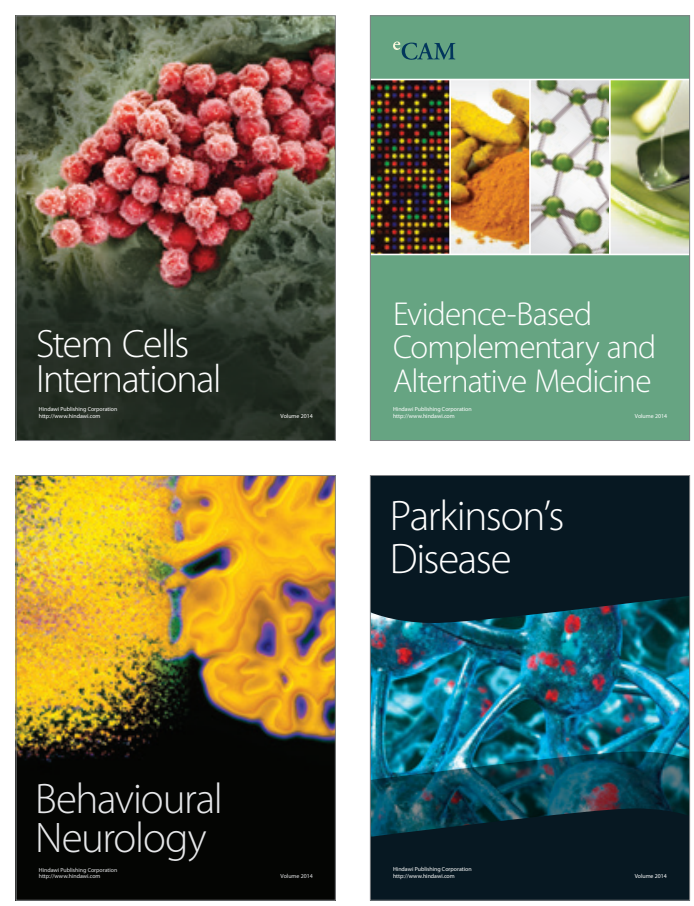



Journal of
Diabetes Research

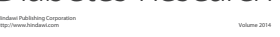



Disease Markers
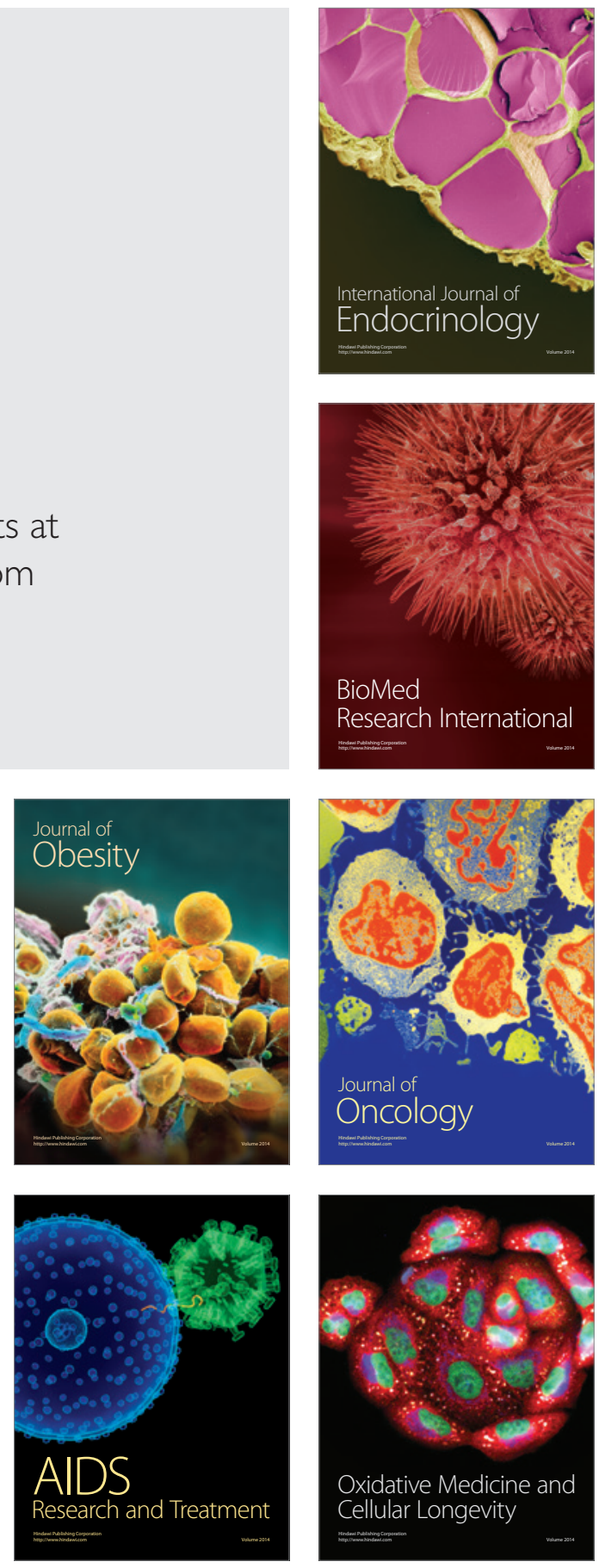